\title{
Facile synthesis of near-infrared responsive on-demand oxygen releasing nanoplatform for precise MRI-guided theranostics of hypoxia-induced tumor chemoresistance and metastasis in triple negative breast cancer
}

Dong Zhang ${ }^{1,3+}{ }^{+}$, Yuanyuan You ${ }^{1,2+}$, Yuan Xu' , Qingqing Cheng ${ }^{1}$, Zeyu Xiao ${ }^{1}$, Tianfeng Chen ${ }^{1,2^{*}} \mathbb{D}$, Changzheng Shi ${ }^{{ }^{*}}$ and Liangping Luo ${ }^{1 *}$

\begin{abstract}
Background: Hypoxia is an important factor that contributes to chemoresistance and metastasis in triple negative breast cancer (TNBC), and alleviating hypoxia microenvironment can enhance the anti-tumor efficacy and also inhibit tumor invasion.

Methods: A near-infrared (NIR) responsive on-demand oxygen releasing nanoplatform ( $\mathrm{O}_{2}$-PPSil) was successfully synthesized by a two-stage self-assembly process to overcome the hypoxia-induced tumor chemoresistance and metastasis. We embedded drug-loaded poly (lactic-co-glycolic acid) cores into an ultrathin silica shell attached with paramagnetic Gd-DTPA to develop a Magnetic Resonance Imaging (MRI)-guided NIR-responsive on-demand drug releasing nanosystem, where indocyanine green was used as a photothermal converter to trigger the oxygen and drug release under NIR irradiation.

Results: The near-infrared responsive on-demand oxygen releasing nanoplatform $\mathrm{O}_{2}$-PPSil was chemically synthesized in this study by a two-stage self-assembly process, which could deliver oxygen and release it under NIR irradiation to relieve hypoxia, improving the therapeutic effect of chemotherapy and suppressed tumor metastasis. This smart design achieves the following advantages: (i) the $\mathrm{O}_{2}$ in this nanosystem can be precisely released by an NIR-responsive silica shell rupture; (ii) the dynamic biodistribution process of $\mathrm{O}_{2}$-PPSil was monitored in real-time and quantitatively analyzed via sensitive MR imaging of the tumor; (iii) $\mathrm{O}_{2}$-PPSil could alleviate tumor hypoxia by releasing $\mathrm{O}_{2}$ within the tumor upon NIR laser excitation; (iv) The migration and invasion abilities of the TNBC tumor were weakened by inhibiting the process of EMT as a result of the synergistic therapy of NIR-triggered $\mathrm{O}_{2}$-PPSil.
\end{abstract}

Conclusions: Our work proposes a smart tactic guided by MRI and presents a valid approach for the reasonable design of NIR-responsive on-demand drug-releasing nanomedicine systems for precise theranostics in TNBC.

\footnotetext{
*Correspondence: tchentf@jnu.edu.cn; tsczcn@jnu.edu.cn; tluolp@jnu.edu.cn

${ }^{\dagger}$ Dong Zhang and Yuanyuan You contributed equally to this work

${ }^{1}$ Department of Medical Imaging Center, The First Affiliated Hospital, Jinan University, Guangzhou 510630, China

Full list of author information is available at the end of the article
} permits use, sharing, adaptation, distribution and reproduction in any medium or format, as long as you give appropriate credit to the original author(s) and the source, provide a link to the Creative Commons licence, and indicate if changes were made. The images or other third party material in this article are included in the article's Creative Commons licence, unless indicated otherwise in a credit line to the material. If material is not included in the article's Creative Commons licence and your intended use is not permitted by statutory regulation or exceeds the permitted use, you will need to obtain permission directly from the copyright holder. To view a copy of this licence, visit http://creativecommons.org/licenses/by/4.0/. The Creative Commons Public Domain Dedication waiver (http://creativecommons.org/publicdomain/zero/1.0/) applies to the data made available in this article, unless otherwise stated in a credit line to the data. 
Keywords: On-demand drug release, MRI-guided theranostics, Tumor hypoxia, Nanoplatform, Triple negative breast cancer

\section{Graphical Abstract}

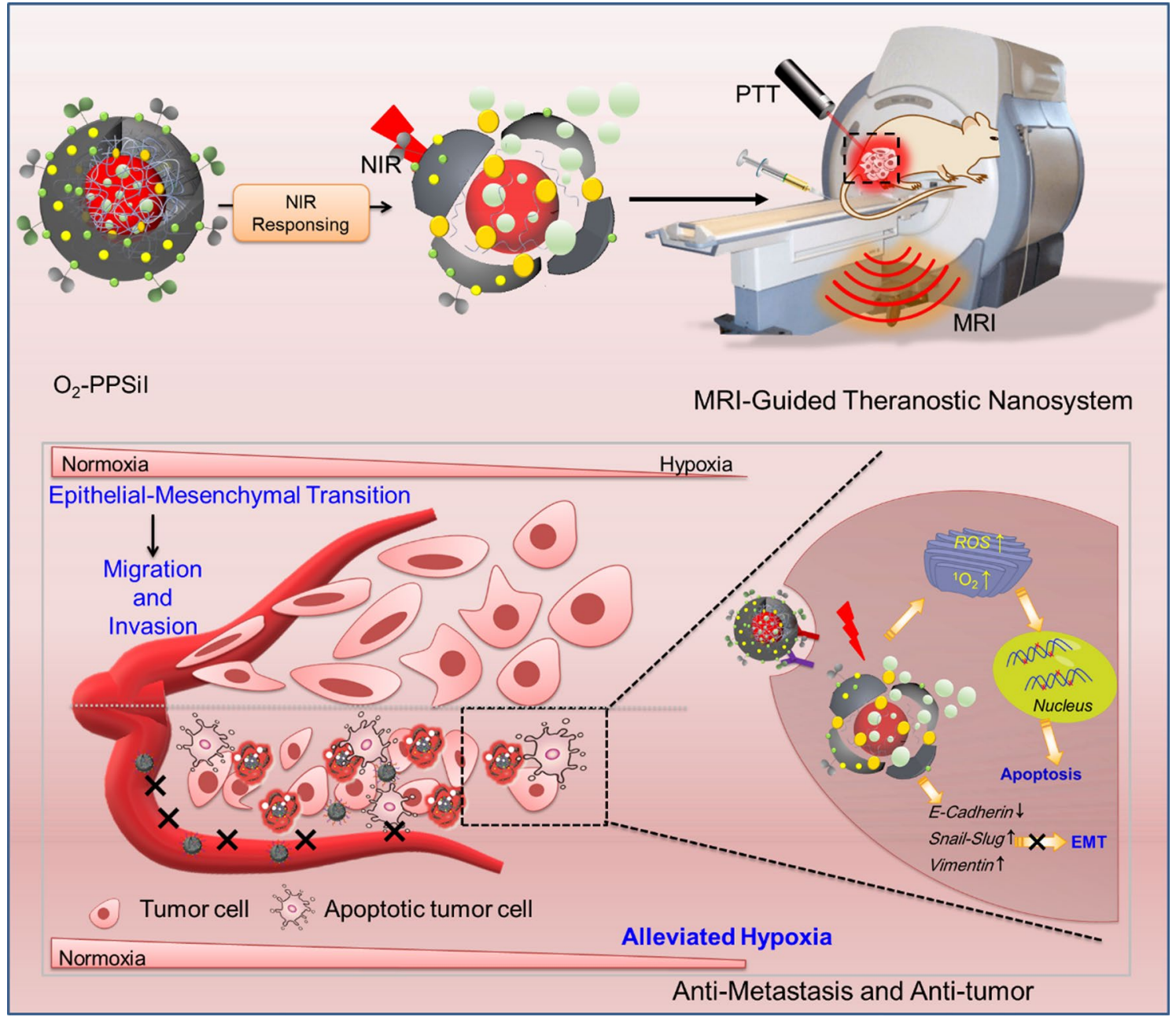

\section{Introduction}

Triple-negative breast cancer (TNBC) accounts for almost $15-20 \%$ of all the breast cancer cases and presents a poor prognosis due to its metastatic nature and high recurrence rate $[1,2]$. Owing to the paucity of ER, PR and HER2, TNBC cannot benefit from the FDA-approved targeted therapies which have been proved to be efficacious for the other breast cancer subtypes $[3,4]$. The systemic chemotherapy using paclitaxel (PTx) remains the first-line treatment of advanced TNBC, but its efficacy is limited by its severe side effects and acquired drug resistance, leading to the failure of chemotherapy and tumor migration and invasion $[5,6]$. The hypoxic tumor microenvironment was reported to be involved in different tumorigenesis mechanisms of TNBC, such as invasion, immune evasion, chemoresistance, and metastasis [7]. Hypoxia is a pathophysiological characteristic for the tumor microenvironment that results in abnormalities in the tumor vasculature and a disproportion between oxygen provision and oxygen utilization in the tumors $[8,9]$. Poor efficacy in hypoxic areas is often linked with the space from cancer cells to supply vessels and the permeability of the newly formed tumor vascular system [10-12]. Meanwhile, hypoxia upregulates the activity of p-glycoprotein in tumor cells, leading to drug resistance of the cells [13]. In addition, most chemotherapeutic agents including PTx induce cytotoxicity by proliferating cells, but hypoxic cancer cells are more likely to proliferate more slowly than normal tissue, resulting in tumor cells tolerant to the chemotherapy. What's more, 
hypoxia has increasingly emerged as a crucial factor of microenvironment in the regulation of tumor metastasis accompanying with the activation of hypoxia-inducible transcription factor (HIF), which could activate the process of epithelial-to-mesenchymal transition (EMT), resulting in tumor metastasis and leading to a multidrug resistance [14-16]. Therefore, hypoxia is an important factor that contributes to TNBC metastasis and multidrug resistance to chemotherapy, and alleviating hypoxia microenvironment can enhance the anti-TNBC efficacy of chemotherapy and also inhibit its invasion and metastasis.

Tumor oxygenation can relieve hypoxia to achieve better therapeutic effects $[17,18]$. For example, producing oxygen in situ with the use of catalysts to promote the degradation of endogenous hydrogen peroxide $\left(\mathrm{H}_{2} \mathrm{O}_{2}\right)$ can relieve tumor hypoxia and strengthen the therapy [19-21]. In addition, improving intertumoral blood flow can also lead to relieved tumor hypoxia $[22,23]$. However, the limited available $\mathrm{H}_{2} \mathrm{O}_{2}$ within the tumor, as well as the poor distribution of oxidized red blood cells reaching the tumor vessels, often leads to an insufficient intratumor oxygen delivery and unsatisfactory tumor reoxygenation. Biocompatible perfluorocarbons (PFCs) have been applied as the artificial blood substitute for many years, which often been used in different nanocarriers to transport oxygen into tumors for alleviating the tumor hypoxia [24-26]. However, $\mathrm{O}_{2}$ is physically dissolved in PFCs and the release of oxygen from PFOB depends on the diffusion between oxygen concentration gradients [27]. This property also makes it difficult to retain high oxygen level in perfluorocarbon-based nanosystems for a long time in the natural state, which would impact the blood circulation time and the oxygen accumulation in tumor. Ensuring the $\mathrm{O}_{2}$ transport stability and rapidity of release was the key aspect for PFCs-based $\mathrm{O}_{2}$ carrier. It has been reported the near-infrared (NIR)-induced photothermal therapy (PTT) not only could kill the tumor [28-30], but also accelerate $\mathrm{O}_{2}$ release from PFCs-based $\mathrm{O}_{2}$ carrier to mitigate tumor hypoxia with remarkably synergistic effects [31,32]. Therefore, sealing off the oxygen in a nanosystem and release it by NIR may be a strategy for delivering $\mathrm{O}_{2}$ to tumor.

Hence, a near-infrared responsive on-demand oxygen releasing nanoplatform $\left(\mathrm{O}_{2}\right.$-PPSiI $)$ was successfully established to delivery $\mathrm{O}_{2}$ to tumor and trigger its release under NIR irradiation. The poly(lactic-co-glycolic acid) (PLGA) was served as a core to load both oxygen carrier perfluorooctyl bromide (PFOB) and the chemotherapy drug PTx. Then, covering the ultrathin-walled silica shell on it was used to seal the $\mathrm{O}_{2}$ in this nanosystem. The Indocyanine green (ICG) served as a photothermal converter to trigger the rupture of silica shell and $\mathrm{O}_{2}$ release. Furthermore, in order to realize the precise and controllable on-demand drug releasing, the non-invasive radiation-free modality MRI and its T1 contrast agent paramagnetic gadolinium $\left(\mathrm{Gd}^{3+}\right)$ complexes, which are all widely used for breast imaging in clinic, was applied to monitor the distribution of nanosystem in real-time. In addition, the Arginine-glycine-aspartic acid (RGD) and urokinase plasminogen activator (uPA), whose receptor integrin $\alpha_{v} \beta_{3}$ and uPAR are overexpressed on human tumor cells [33, 34], were decorated on the surface of $\mathrm{O}_{2}$-PPSiI to transmit the drug into the tumor. The ondemand drug and oxygen release were achieved with an NIR-induced photothermal effect to realize precise treatment against TNBC via synergistic chemotherapy, PTT, and hypoxia mitigation; there were no toxic side effects. In addition, NIR-triggered $\mathrm{O}_{2}$-PPSiI could inhibit the natural procedure of epithelial-mesenchymal transition (EMT) in the TNBC and weaken its migration and invasion ability (Scheme 1). This study offers a smart "Trojan Horse" strategy guided by Gd-enhanced MRI and provides a valid approach for the reasonable design of an NIR-responsive on-demand drug-releasing nanosystem for precise theranostics in TNBC.

\section{Experimental section}

Materials

PLGA, PFOB, tetraethoxysilane (TEOS), and (3-aminopropyl) triethoxysilane (APTES) were bought from Aladdin Company (Shanghai, China). PTX was bought from Macklin Company (Shanghai, China), and ICG was bought from Sigma-Aldrich Company (St. Louis, MO USA). Commercial Gd-DTPA was bought from Shering AG (Berlin, Germany). Targeting ligands uPA and RGD were bought from Sigma-Aldrich Company (St. Louis, MO USA) and GL Biochem Ltd. (Shanghai, China), respectively. Fluorescent probes DHE and DPBF were bought from Sigma-Aldrich Company (St. Louis, MO USA). Antibodies against HIF- $1 \alpha$, Vimentin, Snail-Slug, and E-cadherin were bought from Abcam (Cambridge, UK). The water utilized in this study was distilled.

\section{Synthesis of $\mathrm{O}_{2}$-PPSil}

The synthesis of $\mathrm{O}_{2}$-PPSiI were described previously $[17,35]$. Briefly, the $180 \mu \mathrm{L}$ liquid PFOB and $20 \mathrm{mg}$ PTX were both mixed into a $10 \mathrm{~mL}$ acetone of $70 \mathrm{mg}$ PLGA to form a clear solution. The solution was then added into the cetyltrimethylammonium bromide (CTAB) solution $(0.2 \mathrm{~g} / 40 \mathrm{~mL})$, emulsified by ultrasonic in ice-bath conditions for $10 \mathrm{~min}$, and then completely volatilize acetone at the room temperature. The PFOB/PTX@PLGA nanoparticles (PP) were obtained.

Next, PP solution was dispersed into $45 \mathrm{~mL}$ distilled water and injected into $100 \mathrm{~mL}$ round-bottom flask under 


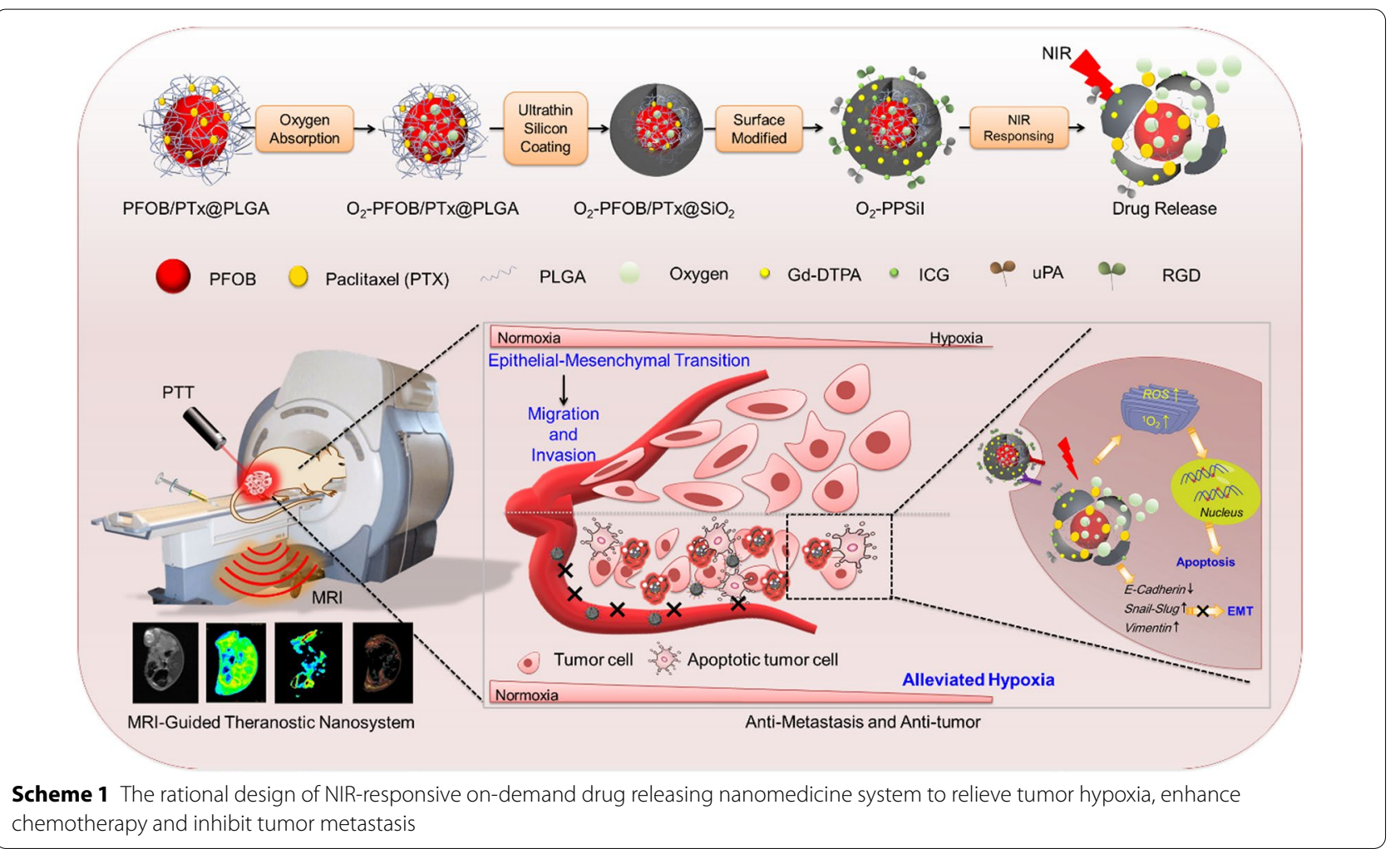

$\mathrm{O}_{2}$ atmosphere. Keeping the Stir at $200 \mathrm{rpm}$ for $1 \mathrm{~h}$ made the nanoparticles fully absorb oxygen. $5 \mathrm{~mL}$ isopropanol was added by stirring for $30 \mathrm{~min}$ followed by the addition $0.5 \mathrm{~mL}$ TEOS and $0.01 \mathrm{~mL}$ APTES. After reacting for $12 \mathrm{~h}$, the products were added into the dichloromethane solution with $50 \mathrm{mg}$ DL-menthol by reaction for another $12 \mathrm{~h}$ at $35^{\circ} \mathrm{C}$, and the $\mathrm{O}_{2}-\mathrm{PFOB} / \mathrm{PTX} @ \mathrm{SiO}_{2}$ nanoparticles $\left(\mathrm{O}_{2}\right.$-PPSiI) were collected by centrifugation. Afterwards, ICG, Gd-DTPA, and $\mathrm{O}_{2}$-PPSiI were mixed in an aqueous solution. After $12 \mathrm{~h}, \mathrm{uPA}$ and RGD linked to the surface of silica shells with the catalysis of 1-ethyl-3-(3-dimethylaminopropyl) carbodiimide hydrochloride (EDC) and $\mathrm{N}$-hydroxysuccinimide (NHS).

\section{Oxygen storage and release of $\mathrm{O}_{2}$-PPSil}

To examine the stability of the oxygen storage in $\mathrm{O}_{2}$-PPSiI, the nanoparticle was dispersed in the deoxygenated water and divided into seven samples for different times at room temperature. A portable oxygen meter (YSI-550A, YSI, USA) was employed to monitor the dissolved $\mathrm{O}_{2}$ concentrations in the solutions excited with an $808 \mathrm{~nm}$ NIR laser at a density of $1.5 \mathrm{~W} / \mathrm{cm}^{2}$ for $6 \mathrm{~min}$.

To examine the performance of oxygen release in $\mathrm{O}_{2}$-PPSiI. An ultrasound imaging device (Philips iU-Elite ultrasound system, USA) was used to visualize the process of oxygen release in $\mathrm{O}_{2}$-PPSiI, and the images of the sample or the tumor before and after irradiation were obtained at a gain of $69 \%$ or $79 \%$, depth of 2.5 or $1.3 \mathrm{~cm}$, and a mechanical index 0.6.

\section{Evaluation of cell migration and invasion}

Cell migration was examined with a wound healing assay. Briefly, MDA-MB-231 cells $\left(2 \times 10^{6}\right.$ cells/well $)$ were seeded into the 6-well plates. After culturing for $24 \mathrm{~h}$, each well was scratched in the middle of the cells. The medium was then taken away, and the cells were washed with PBS, and then the DMEM with 3\% FBS was added. Next, the cells were exposed to different treatment groups with incubation for $24 \mathrm{~h}$. After the addition of Hoechst $33,342(1 \mu \mathrm{g} / \mathrm{mL})$ for $30 \mathrm{~min}$, the images of cell migration were obtained using a fluorescence microscope.

Cell invasion was examined with transwells assay. Briefly, a Boyden transwell chamber (Corning, USA) was added with dissolved ECM gel and incubated for 4-8 $\mathrm{h}$ at $37^{\circ} \mathrm{C}$. MDA-MB-231 cells were added into the DMEM and seeded into the Boyden chamber $\left(5 \times 10^{5}\right.$ cells $\left./ \mathrm{mL}\right)$. A total of $500 \mathrm{~mL}$ DMEM with $10 \%$ FBS was put into the lower chamber. Next, different treatment agents at the same concentration were added into the chamber for $24 \mathrm{~h}$ at $37^{\circ} \mathrm{C}$. Thereafter, the cells that invade through the upper chamber were fixed with methanol, stained with crystal violet, and observed with an inverted optical microscope (Olympus, Japan). 


\section{Establishment of MDA-MB-231 orthotopic xenografts}

All the animal study was performed with the approval of the Animal Experimentation Ethics Committee of Jinan University. Female BALB/c nude mice with 4-5 weeks of age were bought from Vitalriver Inc. (Beijing, China) and raised in a specific pathogen-free environment. The MDA-MB-231 cells at logarithmic growth phase were digested and collected as a suspension $\left(2 \times 10^{5}\right.$ cells $/ 40 \mu \mathrm{L}$ ) followed by injection into the fat pad of the third breast on the right to establish MDA-MB-231 orthotopic xenografts. After growing for about 28 days, the mice with the tumor reached approximately $300 \mathrm{~mm}^{3}$ and were included to perform the next experiments. All the mice were anesthetized with intraperitoneal injection of $2 \%$ pentobarbital $(75 \mu \mathrm{L} / 200 \mathrm{~g})$ sodium salt before the examinations.

\section{In vivo antitumor activity}

To investigate the antitumor activity of $\mathrm{O}_{2}$-PPSiI, the included tumor-bearing mice were divided into 7 groups with the treatment of saline, laser, PTX, $\mathrm{O}_{2}$-PPSil, PPSiI (the nanoparticles without $\mathrm{O}_{2}$ ) irradiated with NIR-laser (simplified as "PPSiI + Laser"), $\mathrm{O}_{2}$-PSiI (the nanoparticles without PTX) irradiated with NIR-laser (simplified as "O ${ }_{2}$-PSiI + Laser") and $\mathrm{O}_{2}$-PPSiI irradiated with NIR-laser (simplified as "O ${ }_{2}$-PPSil+Laser"). All the agents were injected through the caudal vein at equivalent concentration of $10 \mathrm{mg} / \mathrm{kg}$ PTX, and the $808 \mathrm{~nm}$ NIR-laser was used at a density of $2 \mathrm{~W} / \mathrm{cm}^{2}$ for $5 \mathrm{~min}$. All the groups were treated twice a week with an interval of 3 days, and the NIR-laser irradiation was conducted at $8 \mathrm{~h}$ after the intravenous injection which was precisely identified according to the $\mathrm{MR}$ imaging of $\mathrm{O}_{2}$-PPSiI in vivo.

The structural and functional MRI including threedimensional T2-weighted imaging (3D-CUBE T2WI), blood oxygenation level-dependent magnetic resonance imaging (BOLD-MRI) and intravoxel incoherent motion diffusion-weighted imaging (IVIM-DWI) sequences were performed to monitor the antitumor activity of $\mathrm{O}_{2}$-PPSil before and 7 days, 14 days and 21 days after the treatment with a $1.5 \mathrm{~T}$ Signa HDxt superconductor clinical Magnetic resonance system (GE Medical, Milwaukee, U.S.). The 3D-CUBE T2WI was scanned with TR/TE, 2000/83.1 ms; FOV $60 \mathrm{~mm} \times 60 \mathrm{~mm}$; matrix, $192 \times 160$; slice thickness/space, $1.5 / 0 \mathrm{~mm}$; and the volume of each tumor was calculated through volume render program at the post-processing workstation (AW4.5, GE Healthcare). The BOLD-MRI was scanned with TR/TE, 235/3.9-104.7 ms; FOV $50 \mathrm{~mm} \times 50 \mathrm{~mm}$; matrix, $192 \times 128$; slice thickness/space, $2.0 / 0.2 \mathrm{~mm}$; and the R2* was mapped through Functool R2star program at the post-processing workstation (AW4.5, GE
Healthcare). The IVIM-DWI was scanned with TR/TE, $3000 / 101.7 \mathrm{~ms}$; FOV $50 \mathrm{~mm} \times 50 \mathrm{~mm}$; matrix, $128 \times 96$; slice thickness/space, $2.0 / 0.2 \mathrm{~mm}$; b values, $0,25,50$, 75, 100, 150, 200, 400, 600, 800, 1000, 1200 and $1500 \mathrm{~s} /$ $\mathrm{mm}^{2}$; and then the diffusion-related parameter $\mathrm{D}$ and perfusion-related parameter $\mathrm{f}$ was mapped via the Functool MADC program at the post-processing workstation (AW4.5, GE Healthcare). Besides, the body weight of all the mice in each group was also recorded every two days. All the results were normalized to their percentage difference $\left(\triangle \mathrm{X}(\%)=\left(\mathrm{X}^{i}-\mathrm{X}^{\text {base }}\right) / \mathrm{X}^{\text {base }} \times 100 \%\right.$, which $i$ represented the different time points, and $X$ referred to the Volume, R2*, D, f and Body weight as mentioned above). After 21 days, all the mice in each group were sacrificed, and the tumor was separated and weighted, and organs and blood sample were also collected to conduct the hematoxylin and eosin ( $\mathrm{H} \& \mathrm{E})$ staining and biochemical analysis.

\section{Statistical analysis}

All the data are presented with mean \pm standard deviation (SD). Differences among groups were evaluated with one-way analysis of variance (ANOVA) and the least significant difference (LSD) t-test. Pearson correlation analyses between MRI-derived parameters and the expression of E-cadherin, vimentin, and Snail-Slug were performed. A difference of $P<0.05(*)$ or $P<0.001$ $(* *)$ was considered statistically significant. All statistical analyses were completed using the SPSS software package (Version 14.0, SPSS Inc., Chicago, IL, USA).

\section{Results and discussion}

Facile synthesis and characterization of $\mathrm{O}_{2}$-PPSil nanosystem

The $\mathrm{O}_{2}$-PPSiI nanosystem was chemically synthesized by a two-stage self-assembly process, which was the PFOB core as the oxygen carrier, and then encapsulated into an ultrathin-walled silica shell (Fig. 1A). In the first stage, the PFOB core (i.e., the core without the silica coating) was synthesized via an emulsion-(solvent-evaporation) method [35], and PTx was mixed into PLGA to form the PFOB/PTX@PLGA (abbreviated as PP) nanocapsule. And then the PP nanocapsule was used to absorb $\mathrm{O}_{2}$ as a carrier. In the second stage, the ultrathin-walled silica shell was synthesized by hydrolysis and condensation of TEOS. The silica shell was heterogeneous in nature, and thus biocompatible DLmenthol was used to prevent oxygen release from the nanosystem. The loading efficacy of PTX in $\mathrm{O}_{2}$-PPSil was about $20 \%$.

Transmission electronic microscopy (TEM) pictures presented the morphology of $\mathrm{O}_{2}$-PPSi which was a typical spherical shell/core structure (Fig. 1B) with an average diameter of $203 \mathrm{~nm}$ (Fig. 1C). Compared to 


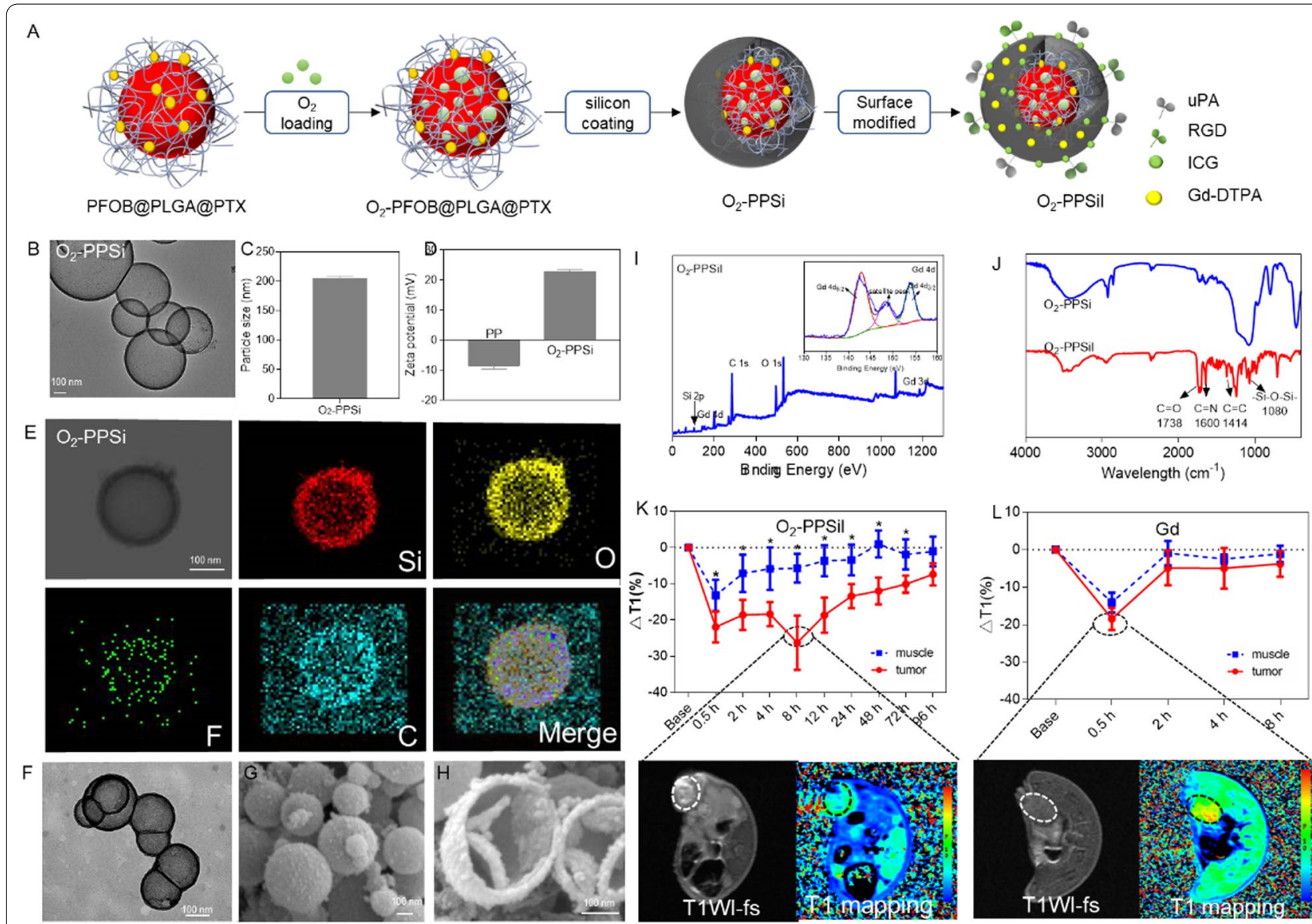

Fig. 1 The Synthesis and structural characterization of $\mathrm{O}_{2}-\mathrm{PPSil}$. A Diagrams for synthetic process of $\mathrm{O}_{2}-\mathrm{PPS}$ il. B TEM image of $\mathrm{O}_{2}-\mathrm{PPSi}$. C The average sizes of $\mathrm{O}_{2}$-PPSi. D The zeta potential of PP and $\mathrm{O}_{2}$-PPSil. E EDS element mapping images of $\mathrm{O}_{2}$-PIr@Si. F TEM image of $\mathrm{O}_{2}$-PPSil. G The SEM image of $\mathrm{O}_{2}$-PPSil. $\mathbf{H}$ The SEM of deliberately selected broken $\mathrm{O}_{2}$-PPSil nanosystem. I The XPS of $\mathrm{O}_{2}$-PPSil. The inserted data is the high resolution $\mathrm{Gd} 4 \mathrm{~d}$ XPS spectra for $\mathrm{O}_{2}$-PPSil. $\mathbf{J}$ The FTIR spectrum of $\mathrm{O}_{2}$-PPSi and $\mathrm{O}_{2}$-PPSil. $\mathbf{K}$ and $\mathbf{L}$ The dynamic accumulation of $\mathrm{O}_{2}$-PPSil and free Gd-DTPA in the tumor monitored by T1WI and T1 mapping-MRI, and significant difference between the muscle and tumor is indicated at $P<0.05\left(^{*}\right)$ level

PP $(-8.8 \mathrm{mV})$, the zeta potential of $\mathrm{O}_{2}$-PPSi elevated to $+22.9 \mathrm{mV}$ (Fig. 1D), which is due to the formation of the aminated silica shell on the PP surface. The elemental mapping images of $\mathrm{O}_{2}$-PPSi nanoparticles showed the presence of Si and F elements (Fig. 1E), which further verified the loading of $\mathrm{PFOB}$ and coating of the silica shell. Benefiting from the rich amino and silicon hydroxyl groups on the surface, the tumor-targeting ligands UPA and RGD were covalently modified to the surface of $\mathrm{O}_{2}$-PPSi nanoparticles; photothermal agent ICG and MR contrast agent Gd-DTPA (Gd) were also added by electrostatic interaction. The morphology of the nanosystem (named $\mathrm{O}_{2}$-PPSiI) was also observed by TEM and scanning electron microscopy (SEM). Figure $1 \mathrm{~F}$ and $\mathrm{G}$ show uniform $\mathrm{O}_{2}$-PPSiI with an average diameter of $203 \mathrm{~nm}$, and the thickness of silicon shell with the decoration on its surface was about $8 \mathrm{~nm}$ (Fig. 1H).
The X-ray photoelectron spectroscopy (XPS) and Fourier transform infrared spectroscopy (FTIR) results further proved that the $\mathrm{O}_{2}$-PPSiI was successfully synthesized. The silicon and the gadolinium peaks were seen in the XPS survey spectra for the surfaces of $\mathrm{O}_{2}$-PPSiI, suggesting that the silica shell and Gd-DTPA were successfully coated and modified on the shell of $\mathrm{O}_{2}$-PPSiI (Fig. 1I). The high resolution Gd 4d XPS spectra for $\mathrm{O}_{2}$-PPSiI inserted in Fig. 1I revealed that the characteristic peaks centered at $142.8 \mathrm{eV}$ and $153.7 \mathrm{eV}$ could be attributed to $G d 4 d_{5 / 2}$ and $G d 4 d_{3 / 2}$, suggesting the existence of Gd (III), which derived from Gd-DTPA [36]. A satellite peak at $148.2 \mathrm{eV}$ in the Gd 4d XPS spectra may derived from the coordinate bond of Gd (III) and DTPA. The XPS spectrum of $\mathrm{C} 1 \mathrm{~s}$ is shown in $\mathrm{O}_{2}$-PPSi (Additional file 1: Fig. S1A), and the peak components at $284.5 \mathrm{eV}$ and $286.6 \mathrm{eV}$ were appointed to the $\mathrm{C}-\mathrm{C}$ and $\mathrm{C}-\mathrm{N}$ groups, respectively. These were attributed to 
APTES on the surface of $\mathrm{O}_{2}$-PPSi. After ICG and GdDTPA grafting on the surface of $\mathrm{O}_{2}$-PPSi, two new peaks at an energy of $284.7 \mathrm{eV}$ and $288.3 \mathrm{eV}$ were seen and could be attached to the $\mathrm{C}=\mathrm{C}$ and $\mathrm{C}=\mathrm{O}$ group, respectively (Additional file 1: Fig. S1B). The chemical structure of $\mathrm{O}_{2}$-PPSiI was analyzed using FTIR. Versus the FTIR spectrum of $\mathrm{O}_{2}-\mathrm{PPSi}$, the broad band at $\approx 1600 \mathrm{~cm}^{-1}$ resulted from the $\mathrm{C}=\mathrm{N}$ band and the peaks at $1414 \mathrm{~cm}^{-1}$ that are represented by the vibrational stretching of the $\mathrm{C}=\mathrm{C}$ groups (Fig. 1J), which are from the ICG. The spectrum of DTPA exhibited the characteristic peak of the asymmetric and symmetric carbonyl $(\mathrm{C}=\mathrm{O})$ stretch of anhydride at $1738 \mathrm{~cm}^{-1}$. Meanwhile, a characteristic UV absorption spectra peak of ICG emerged at $808 \mathrm{~nm}$ after the ICG was grafted on the surface of $\mathrm{O}_{2}$-PPSi (Additional file 1: Fig. S2), which matched the wavelength of the NIR laser applied for PTT. Versus the $\mathrm{O}_{2}-\mathrm{PPSi}$, the color change of $\mathrm{O}_{2}$ - PPSiI indicated that the ICG was coated on the surface (Additional file 1: Fig. S3).

We also evaluated the magnetic properties of $\mathrm{O}_{2}$-PPSiI using T1-weighted imaging (T1WI) and T1 mapping MRI, and the results showed that the T1WI signal of nanosystem was linear and concentration-dependent. The T1 relaxivity ( $\mathrm{r} 1$ ) of $\mathrm{O}_{2}$-PPSiI to be $27.812 \mathrm{mM}^{-1} / \mathrm{s}^{-1}$ (Additional file 1: Fig. S4), and it was dramatically superior than the free Gd-DTPA $\left(4-5 \mathrm{mM}^{-1} / \mathrm{s}^{-1}\right)$, indicating a favorable T1WI contrast effect of $\mathrm{O}_{2}$-PPSiI. These results demonstrated that $\mathrm{O} 2-\mathrm{PPSiI}$ could enhance $\mathrm{T} 1$ positive contrast. Therefore, we further examined the accumulation of $\mathrm{O}_{2}$-PPSiI in vivo by MRI. The accumulation of $\mathrm{O}_{2}$-PPSiI in the tissue was quantitatively evaluated by the decrease of $\mathrm{T} 1$ value (longitudinal relaxation time, normalized as $\triangle \mathrm{T} 1$ to the base). The injected $\mathrm{O}_{2}$-PPSil was selectively accumulated in the tumor and reached its maximum at $8 \mathrm{~h}(\triangle \mathrm{T} 126.28 \%)$ after the systemic administration in vivo (Additional file 1: Fig. 1K). However, the accumulation of Gd-DTPA had no significant selectivity between the tumor and normal muscle tissue. It reached the maximum at $30 \mathrm{~min}(\triangle \mathrm{T} 1 \mathrm{18.45 \%})$ but recovered to baseline after injection for $2 \mathrm{~h}$ (Fig. 1L). These results demonstrated that $\mathrm{O}_{2}$-PPSil could enhance T1 positive contrast of Gd-DTPA and tumor targeting ability against TNBC in vivo.

\section{Photothermal ability of $\mathrm{O}_{2}$-PPSil nanosystem}

The photothermal ability of $\mathrm{O}_{2}$-PPSiI was then examined in this study. The absorption of $\mathrm{O}_{2}$-PPSiI at $750-850 \mathrm{~nm}$ showed obvious concentration dependence (Fig. 2A). The extinction coefficient of $\mathrm{O}_{2}$-PPSiI at $808 \mathrm{~nm}$ for different concentrations was $82.16 \mathrm{Lg}^{-1} \mathrm{~cm}^{-1}$ (Additional file 1: Fig. S5), indicating that the $\mathrm{O}_{2}$-PPSiI nanosystem has high photothermal-conversion performance due to ICG modification. The photothermal-conversion efficiency $(\eta)$ of the $\mathrm{O}_{2}$-PPSiI nanosystem was determined as $45.45 \%$ based upon the data analysis in Fig. 2B and C. To estimate the photothermal-conversion performance of $\mathrm{O}_{2}$-PPSiI, it was stimulated by an $808 \mathrm{~nm}$ NIR laser with increased power densities $\left(0.5,1.0,1.5\right.$, and $\left.2 \mathrm{~W} \mathrm{~cm}^{-2}\right)$ when the concentration was locked at $300 \mu \mathrm{g} \mathrm{mL}^{-1}$. As shown in Fig. 2D, the temperature elevation of $\mathrm{O}_{2}$-PPSiI increased by $35{ }^{\circ} \mathrm{C}$ (reached $61{ }^{\circ} \mathrm{C}$ ) over 3 min of irradiation $\left(1.0 \mathrm{~W} \mathrm{~cm}^{-2}\right)$, and the thermal pictures of this process were documented with an IR thermal camera (Additional file 1: Fig. S6), demonstrating that $\mathrm{O}_{2}$-PPSiI had an excellent photothermal-conversion performance. The packaging of ICG in $\mathrm{O}_{2}$-PPSiI can contribute to the improvement of photostability versus free ICG, as proved with a reducible photothermal effect under repeated laser cycling for five cycles [37] (Additional file 1: Fig. S7).

\section{NIR-triggered $\mathrm{O}_{2}$ release and drug delivery}

The system has NIR-induced photothermal effects from ICG and active oxygen release in PFOB [38]. We encapsulated the oxygen reservoir and antitumor agent into the nanocore and developed an NIR-responsive on-demand drug releasing nanomedicine system to overcome the drug leakage of conventional nano-based drug delivery system (NDDSs). We measured the $\mathrm{O}_{2}$ concentration change of $\mathrm{O}_{2}$-PPSiI in deoxygenated water under a nitrogen atmosphere and found that the $\mathrm{O}_{2}$ concentration increased significantly in the $\mathrm{O}_{2}$-PPSiI solution; many bubbles appeared with longer NIR irradiation times (Fig. 2E and Additional file 1: Fig. S8). Subsequently, ultrasound imaging was used to visualize the NIR-triggered $\mathrm{O}_{2}$ release and drug delivery in vitro. Figure $2 \mathrm{~F}$ and Additional file 1: Fig. S9 show an apparent enhanced echo intensity in the $\mathrm{O}_{2}$-PPSiI solution after NIR irradiation. This was further confirmed via successful development of the NIR-responsive on-demand drug releasing nanomedicine system in this study. Meanwhile, the $\mathrm{O}_{2}$ concentration of the $\mathrm{O}_{2}$-PPSiI solution without NIR irradiation at room temperature showed no obvious change within $24 \mathrm{~h}$ (Fig. 2G), suggesting that the stability of $\mathrm{O}_{2}$-PPSiI was favorable. This proved that the $\mathrm{O}_{2}$-PPSiI has higher $\mathrm{O}_{2}$ storage ability than other $\mathrm{O}_{2}$ delivery nanosystems. The temperature elevation of $\mathrm{O}_{2}$-PPSiI with NIR laser irradiation was the key contributor of oxygen release from $\mathrm{O}_{2}$-PPSiI. Figure 2G and Additional file 1: Fig. S10 show that the morphology of $\mathrm{O}_{2}$-PPSiI swelled and then gradually collapsed at $60{ }^{\circ} \mathrm{C}$ and $70{ }^{\circ} \mathrm{C}$ when the reaction temperature reached $50{ }^{\circ} \mathrm{C}$. This indicates that the $\mathrm{O}_{2}$ release from $\mathrm{O}_{2}$-PPSiI was accompanied with the structural collapse of the $\mathrm{SiO}_{2}$ shell.

Subsequently, the $\mathrm{O}_{2}$ probe $\left[\mathrm{Ru}(\mathrm{dpp})_{3}\right] \mathrm{Cl}_{2}$ (RDPP) which is prone to luminescence quenching by oxygen was used to monitor cellular $\mathrm{O}_{2}$-evolving. As displayed 


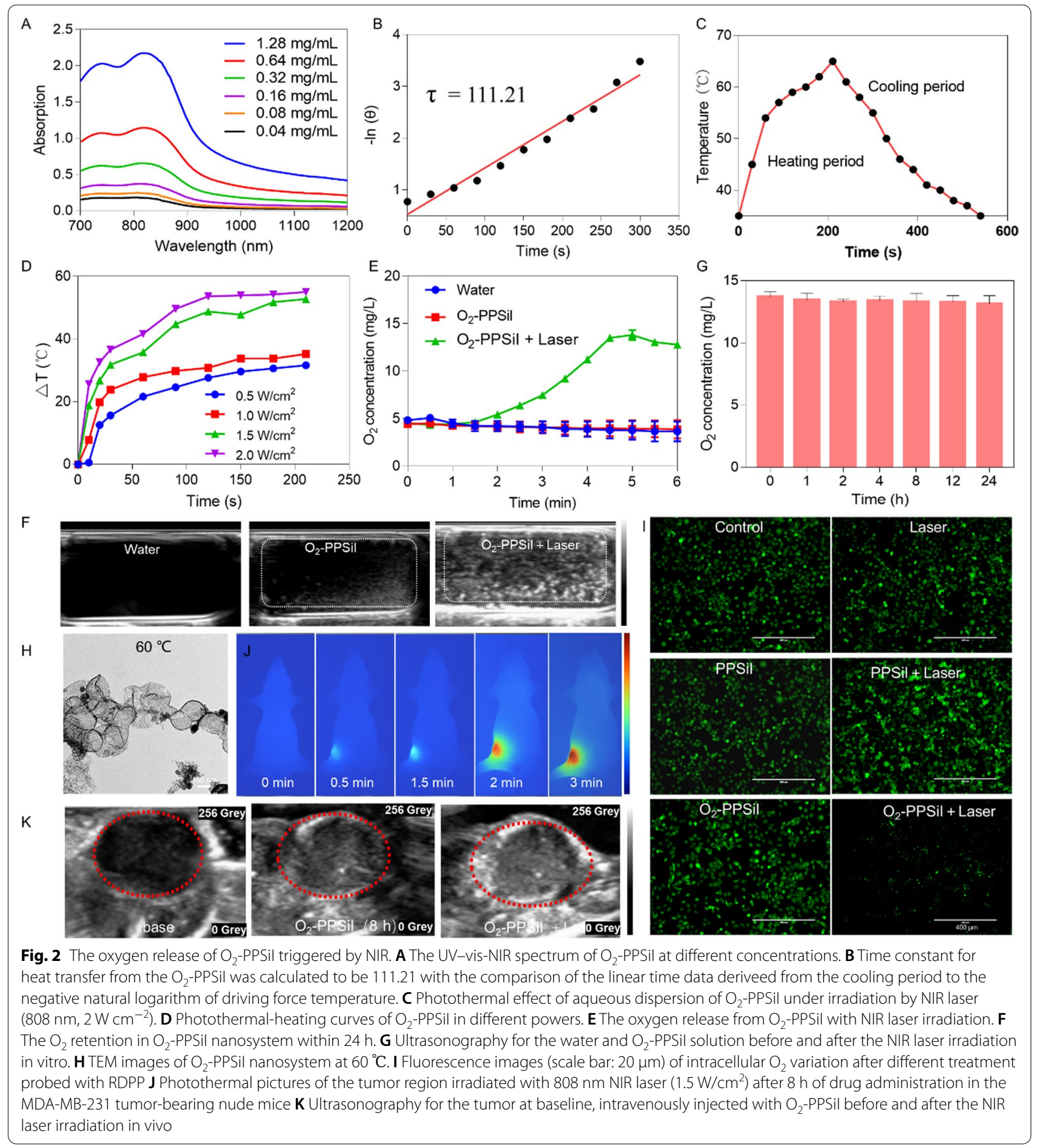

in Fig. 2I, comparing with the control group and PPSiI (the nanosystem without $\mathrm{O}_{2}$ ) group, the MDA-MB-231 cells in $\mathrm{O}_{2}$-PPSiI + Laser group showed a weak green fluorescence signal because the NIR irradiation triggered $\mathrm{O}_{2}$-release from $\mathrm{O}_{2}$-PPSiI. The photothermal-conversion performance of $\mathrm{O}_{2}$-PPSiI and the $\mathrm{O}_{2}$ release from
$\mathrm{O}_{2}$-PPSiI nanosytem in vivo were further investigated via an IR thermal camera and ultrasound imaging. The outward temperature of tumor treated with $\mathrm{O}_{2}$-PPSiI gradually increased from 35 to $60{ }^{\circ} \mathrm{C}$ along with the laser irradiation time came to $3 \min \left(808 \mathrm{~nm}, 1 \mathrm{~W} \mathrm{~cm}{ }^{-2}\right.$; Fig. 2J). This temperature increase could ablate the 
tumor. Moreover, the ultrasound images recorded the $\mathrm{O}_{2}$ release process under the laser irradiation (Fig. $2 \mathrm{~K}$ and Additional file 1: Fig. S11). These results demonstrated that $\mathrm{O}_{2}$-PPSiI offered NIR-responsive on-demand drugrelease in vitro and in vivo.

\section{Distribution of $\mathrm{O}_{2}$-PPSil nanosystems in vivo}

The targeting efficacy of the nanoparticle to by RGD and uPA to TNBC was investigated. We firstly compared the intracellular uptake of $\mathrm{O}_{2}$-PPSiI between MDAMB-231 cells and normal breast cells (Hs 578Bst), and the $\mathrm{O}_{2}$-PPSiI exhibited much higher cellular uptake in MDA-MB-231 cells, but obvious lower in normal breast cells (Additional file 1: Fig. S12A and B). And then, the targeted molecule competition assay further proved that the highly selective intracellular uptake of $\mathrm{O}_{2}$-PPSiI in MDA-MB-231 cells was mediated by the RGD and uPA (Additional file 1: Fig. S12C). In addition, the targeting efficacy in vivo of the nanoparticle to by RGD and uPA to triple negative breast cancer was detected by using nanosystem with or without different targeting molecule the bio fluorescence imaging. As shown in Additional file 1: Fig. S12D, the double targeted-nanosystem $\left(\mathrm{O}_{2}\right.$-PPSiI with uPA and RGD) has a higher accumulation in tumor than the $\mathrm{O}_{2}$-PPSiI nanosystem with uPA or RGD. These results proved the design of double targeting molecule could result in the high targeting efficacy of $\mathrm{O}_{2}$-PPSiI to TNBC. Subsequently, MRI was used to monitor the distribution of the $\mathrm{O}_{2}$-PPSiI nanosystem in vivo at various time points. Figure $3 \mathrm{~A}$ shows that intravenously injected $\mathrm{O}_{2}$-PPSiI was selectively accumulated in the tumor region and came to its maximum at $8 \mathrm{~h}$. Therefore, dual modal imaging can effectively and precisely monitor the distribution of the $\mathrm{O}_{2}$-PPSiI nanosystem in vivo and confirm the best time point of NIR irradiation.

Transporting the drugs to the deep tumor tissue is limited owing to abnormal angiogenesis and irregular tumor blood flow. Currently, functional nanosystems have provided new strategies to enhance tumor penetration and achieve effective and successful antitumor therapy [39]. Here, intravoxel incoherent motion diffusion-weighted imaging (IVIM-DWI) was used to evaluate the in vivo tumor vascularity. As a non-contrast-based functional MRI sequence, IVIM-DWI is an attractive approach to assess not only the tumor cellularity but also the microperfusion with no need to use exogenous contrast agents. This allows it to be repeatedly used as a method of quantitatively monitoring the therapeutic response in vivo [40]. In this work, we applied IVIM-DWI to evaluate the microperfusion of the baseline tumors, and then drew two orthogonal lines in the Dorsal/Ventral (Do/Ve) and Medial/Lateral $(\mathrm{Me} / \mathrm{La})$ directions crossing the tumor center. This divided each radius into 10 segments with equivalent lengths (each segment was then appointed with a figure of $1-10$, i.e., the outermost segment was appointed with 1 and the innermost segment of 10 at a radial position). We then confirmed the heterogeneous vascularity of TNBC and found that the intratumor blood flow at the normalized radius $\geq 6$ in both the Ve/ Do and La/Me direction was significantly decreased versus the outermost segment (Fig. 3B and C), which was also observed by Gaustad [41]. Based on these results, we further divided the entire tumor into peripheral (the outermost segment 1 to segment 5) and central (segment 6 to the innermost segment 10) zones. The injected $\mathrm{O}_{2}$-PPSiI infiltrated deep into the central region with no significant difference in $\triangle \mathrm{T} 1$ versus the peripheral zone (Fig. 3D). The Gd-DTPA mainly accumulated in the peripheral region and presented a lower $\triangle \mathrm{T} 1$ than the central zone (Fig. 3E). These results confirmed a favorable intratumor penetration of $\mathrm{O}_{2}$-PPSiI, and the potential mechanism may be associated with the cell-to-cell transport through the active targeting of UPAR in the tumor and stromal cells [42].

We further investigated the biodistribution of injected $\mathrm{O}_{2}$-PPSiI in the tumor-bearing nude mice. The T1 MRI data presented that, except for the intratumor accumulation, the injected $\mathrm{O}_{2}$-PPSiI was mainly collected by the kidney within $24 \mathrm{~h}$ (Additional file 1: Fig. S13A). It had a fluctuating yet increasing trend in $\triangle \mathrm{T} 1$ after $24 \mathrm{~h}$ (Additional file 1: Fig. S13B), which may reflect the urinary excretion of $\mathrm{O}_{2}$-PPSiI. In addition, the injected $\mathrm{O}_{2}$-PPSiI was also taken up by the liver and spleen that showed a fluctuating change in $\triangle T 1$ (Additional file 1: Fig. S14CD). Moreover, the fluorescence images showed most of the injected O2-PPSil accumulated in the intestinal system within $8 \mathrm{~h}$, and then vanished gradually after $12 \mathrm{~h}$ excepted for the retention in the tumor region. These results indicated a urinary and intestinal excretion of the $\mathrm{O}_{2}$-PPSiI, further confirming its favorable biodegradability in tumor theranostics.

\section{Antagonizing tumor hypoxia statues by NIR-triggered oxygen release in vivo}

Hypoxia offers multiple problems in the treatment of cancers [43]. Antagonizing tumor hypoxia statues is important for tumor therapy $[44,45]$. Therefore, the efficacy of relieving tumor hypoxia for $\mathrm{O}_{2}$-PPSiI nanosystems was further investigated with MDA-MB-M231 tumorbearing nude mice. First, based upon the paramagnetic effect of deoxyhemoglobin, we used blood oxygenation leveldependent magnetic resonance imaging (BOLD-MRI) to monitor the realtime improvements in tumor hypoxia as well as the efficacy of NIR-triggered oxygen-shuttle nanomedicine in promoting tumor oxygenation. Improvements in tumor hypoxia were evaluated quantitatively 


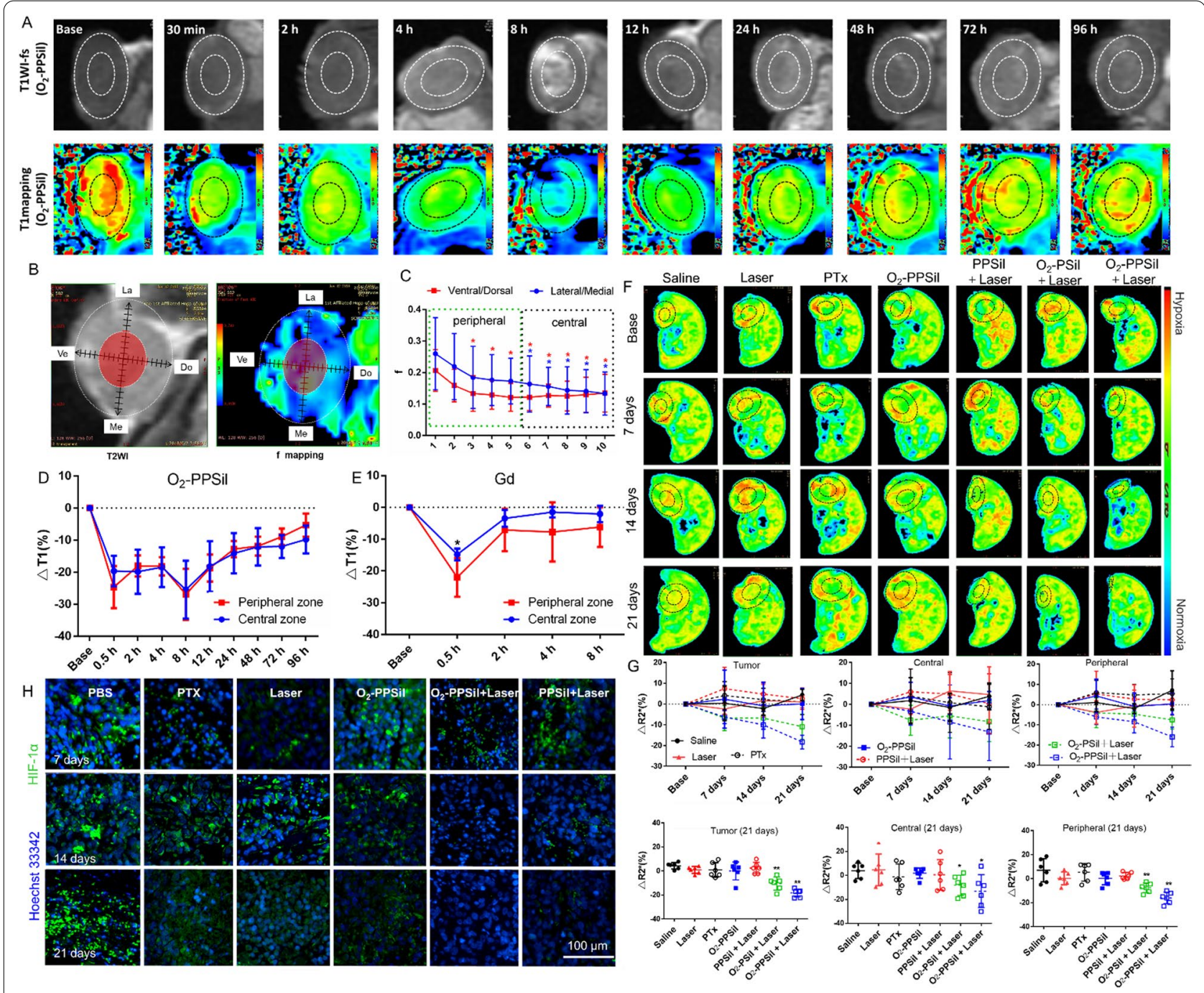

Fig. 3 The distribution of $\mathrm{O}_{2}$-PPSil in vivo. A The representative images of T1WI and T1 mapping-MRI for the dynamic accumulation of $\mathrm{O}_{2}-$ PPSil in tumor. B, C The confirmation of tumor central and peripheral zones based on IVIM-DWI derived $\mathrm{f}$ mapping, and significant difference between the outermost segment ("1") and inner segments ("2-10") is indicated at $P<0.05\left(^{*}\right)$ level. (D, E) The dynamic accumulation of $\mathrm{O}_{2}-$ PPSil and free Gd-DTPA in the tumor central and peripheral zones monitored, and significant difference between the peripheral and central tumor is indicated at $P<0.05$ ${ }^{*}$ ) level. $(\mathbf{F}, \mathbf{G})$ The representative images for $R 2^{*}$ mapping and the relative changes of $R 2^{*}$ value $\left(\triangle R 2^{*}\right)$ of the whole tumor, central tumor and peripheral tumor in each groups before and after the treatments, and significant difference between the Saline and treatment groups is indicated at $P<0.05\left(^{*}\right)$ or $\left.P<0.001{ }^{* *}\right)$ level. $\mathbf{H}$ Representative immunofluorescence pictures of tumor slices stained with the Anti-HIF-a (green)

using the decreased R2* values of BOLD-MRI [46]. Figure $3 \mathrm{~F}$ shows that the tumors treated with NIR-triggered $\mathrm{O}_{2}$-PPSiI and $\mathrm{O}_{2}$-PSiI (without PTX, $808 \mathrm{~nm}, 1 \mathrm{~W} \mathrm{~cm}^{-2}$ ) demonstrated a reduction in $R_{2}^{*}$ (normalized as $\triangle R 2^{*}$ to the base) versus the baseline in both the central and peripheral zones. These results proved a satisfactory tumor oxygenation level in the local tissue. Versus the saline group, the tumors treated with a single NIR laser, PTX, and $\mathrm{O}_{2}$-PPSiI showed no significant difference in $\triangle R 2^{*}$, while the NIR-triggered $\mathrm{O}_{2}$-PPSiI and $\mathrm{O}_{2}$-PSiI treatment groups had a significant decrease in $\triangle R 2^{*}$ at the endpoints of the treatment in both the central and peripheral zone (Fig. 3G). The tumor treated with NIRtriggered PPSiI was considered as a negative control to verify the contribution of $\mathrm{O}_{2}$ release for the tumor hypoxia relieving effect. Versus the NIR-triggered PPSil group, the tumor treated with NIR-triggered $\mathrm{O}_{2}$-PPSil showed a significantly decreased $\triangle \mathrm{R} 2^{*}$ in both the central and peripheral zones, which further proved the improvements in tumor hypoxia statues by NIR-triggered oxygen release [47]. Furthermore, we performed HIF-1 $\alpha$ immunofluorescence staining to confirm the efficacy of 
NIR-triggered $\mathrm{O}_{2}$-PPSiI in promoting tumor oxygenation (Fig. $3 \mathrm{H}$ ). Consistent with the results of BOLD-MRI, the tumor treated with NIR-triggered $\mathrm{O}_{2}$-PPSiI showed a decreased expression of HIF-1 $\alpha$. But then, tumors treated with single NIR, PTX, $\mathrm{O}_{2}$-PPSiI, and NIR-triggered PPSiI exhibited high expression of HIF- $1 \alpha$ with strong green immunofluorescence in different levels. The BOLDMRI and immunofluorescence staining data suggested that NIR-triggered $\mathrm{O}_{2}$-PPSiI could mitigate the hypoxia microenvironment of TNBC in vivo, especially to the central tumor that presented as an avascular region with poor blood flow.

\section{Synergistic therapeutic efficacy of NIR-triggered $\mathrm{O}_{2}$-PPSil}

The in vitro cytotoxicity of the $\mathrm{O}_{2}$-PPSiI nanosystem was investigated with MDA-MB-231 cells by MTT [48]. Additional file 1: Fig. S14 shows that the viability of the cell treated with NIR irradiated $\mathrm{O}_{2}$-PPSiI reduced to $17.8 \%$. Meanwhile, the MDA-MB-231 cells treated with PTX and NIR irradiated PPSiI and $\mathrm{O}_{2}$-PSiI exhibited higher cell viabilities of $55.9 \%, 35.1 \%$, and $48.2 \%$, respectively. The excellent cancer cell killing efficiency for NIR irradiated $\mathrm{O}_{2}$-PPSiI nanosystem in vitro could be attributed to the hyperthermia of ICG and the chemotherapeutic effect of PTX releasing from the $\mathrm{O}_{2}$-PPSiI nanosystem.

To further investigate the cancer cell killing mechanism of $\mathrm{O}_{2}$-PPSiI in vitro, we measured the $\mathrm{ROS}$ and ${ }^{1} \mathrm{O}_{2}$ generated by $\mathrm{O}_{2}$-PPSiI [49]. Versus PTX and NIR-triggered PPSiI, $\mathrm{O}_{2}$-PPSiI under NIR laser irradiation showed more high-efficiency ROS and ${ }^{1} \mathrm{O}_{2}$ generation in solution and MDA-MB-231 cells (Additional file 1: Fig. S15), indicating an important role of $\mathrm{O}_{2}$ release in the production of ${ }^{1} \mathrm{O}_{2}$ and ROS $[50,51]$. Subsequently, the in vivo synergistic antitumor effect of the NIR-triggered $\mathrm{O}_{2}$-PPSiI nanosystem was further investigated with MDA-MB231-bearing nude mice. Based on the precise monitoring for the distribution of $\mathrm{O}_{2}$-PPSiI with T1 mapping MRI in vivo (Fig. 3A), the NIR irradiation was triggered at $8 \mathrm{~h}$ after the injection of PPSiI, $\mathrm{O}_{2}$-PSiI, or $\mathrm{O}_{2}$-PPSiI. The relative changes of tumor volume and weight are revealed in Fig. 4A-C. Over 21 days of treatment, the relative tumor volume (normalized as $\triangle$ Volume to the base) of mice treated with only saline, $\mathrm{O}_{2}$-PPSiI, and NIR irradiation groups increased significantly (Fig. 4A). The mice treated with PTx and NIR-triggered $\mathrm{O}_{2}$-PSiI (without PTX) presented a slightly increased tumor volume compared to day 0 , demonstrating the moderate tumor inhibition of the single chemotherapy and phototherapy against TNBC. However, the tumor volume of mice treated with NIR-triggered PPSiI showed no significant difference at 14 days and 21 days compared to day 0 , while the NIRtriggered $\mathrm{O}_{2}$-PPSiI group showed significantly decreased tumor volumes (Fig. 4B), and the volume as well as the tumor weight at the endpoint of both the groups were significantly lower than the PTX and NIR-triggered $\mathrm{O}_{2}$-PSiI groups (Fig. 4C), demonstrating an obvious inhibition and regression effect of the synergistic chemophototherapy. After treatment for 21 days, the picture of separated tumors in each group also presented similar results as the tumor volume and weight revealed above (Additional file 1: Fig. S16). Moreover, the tumor volume and weight of the mice treated with NIR-triggered $\mathrm{O}_{2}$-PPSiI were significantly lower than those treated with NIR-triggered PPSiI after 21 days coincided with the results of 3D-CUBE T2WI at 21 days (Fig. 4D). The excellent antitumor efficiency in vivo for the NIR-triggered $\mathrm{O}_{2}$-PPSiI nanosystem could be ascribed to an enhanced synergistic chemo-phototherapy efficiency induced by $\mathrm{O}_{2}$ release triggered by NIR laser irradiation.

To further investigate the antitumor effect of the NIRtriggered $\mathrm{O}_{2}$-PPSiI in vivo, the parameters of IVIM-DWI ( $\mathrm{D}$ and $\mathrm{f}$ value) were applied to track the tumor cellularity and perfusion during the therapy [52]. Figure 4E and Additional file 1: Fig. S17 showed the $\triangle D$ value (normalized as $\triangle D$ to the base) in both the central and peripheral regions of the NIR-triggered $\mathrm{O}_{2}$-PPSiI group increased significantly compared the PTX, NIR-triggered $\mathrm{O}_{2}$-PSiI, and PPSiI groups, which demonstrated a reduced cellular density and activity of the tumor in vivo [53]. The results suggest that the enhanced synergistic chemo-phototherapy efficacy induced by tumor hypoxia improvement under NIR laser irradiation could effectively inhibit the tumor cell proliferation especially to the avascular central tumor. Moreover, tumor progression was suppressed by the synergistic chemo-phototherapy which was confirmed with microscopic analysis of tumor tissues stained by hematoxylin and eosin (H\&E). Figure $4 \mathrm{~F}$ shows that $\mathrm{O}_{2}$-PPSiI under NIR laser irradiation could effectively decrease the cell viability in tumor regions which offering an additional support for the

\footnotetext{
(See figure on next page.)

Fig. 4 In vivo antitumor therapeutic efficacy for NIR-triggered $\mathrm{O}_{2}$-PPSil. A-C The relative changes of volume ( $\triangle$ Volume) in each groups before and after the treatments, together with the $\triangle$ Volume and weight of tumors of each groups at the 21 days after the treatment. Significant difference between the Saline and treatment groups is indicated at $P<0.05\left(^{*}\right)$ or $P<0.001\left(^{* *}\right)$ level. D The representative images for tumor volume derived from 3D-CUBE T2WI in each group at the 21 days after the treatment. E IVIM-DWI derived D mapping of tumor in each group before and after the treatment. F, G The corresponding HE and TUNEL staining images at the 21 days after the treatment. (G1:Saline; G2:Laser; G3:PTX; G4: O2-PPSil; G5:PPSil + Laser; G6:O⿰- - PSil + Laser; G7: $\mathrm{O}_{2}$-PPSil + Laser)
} 

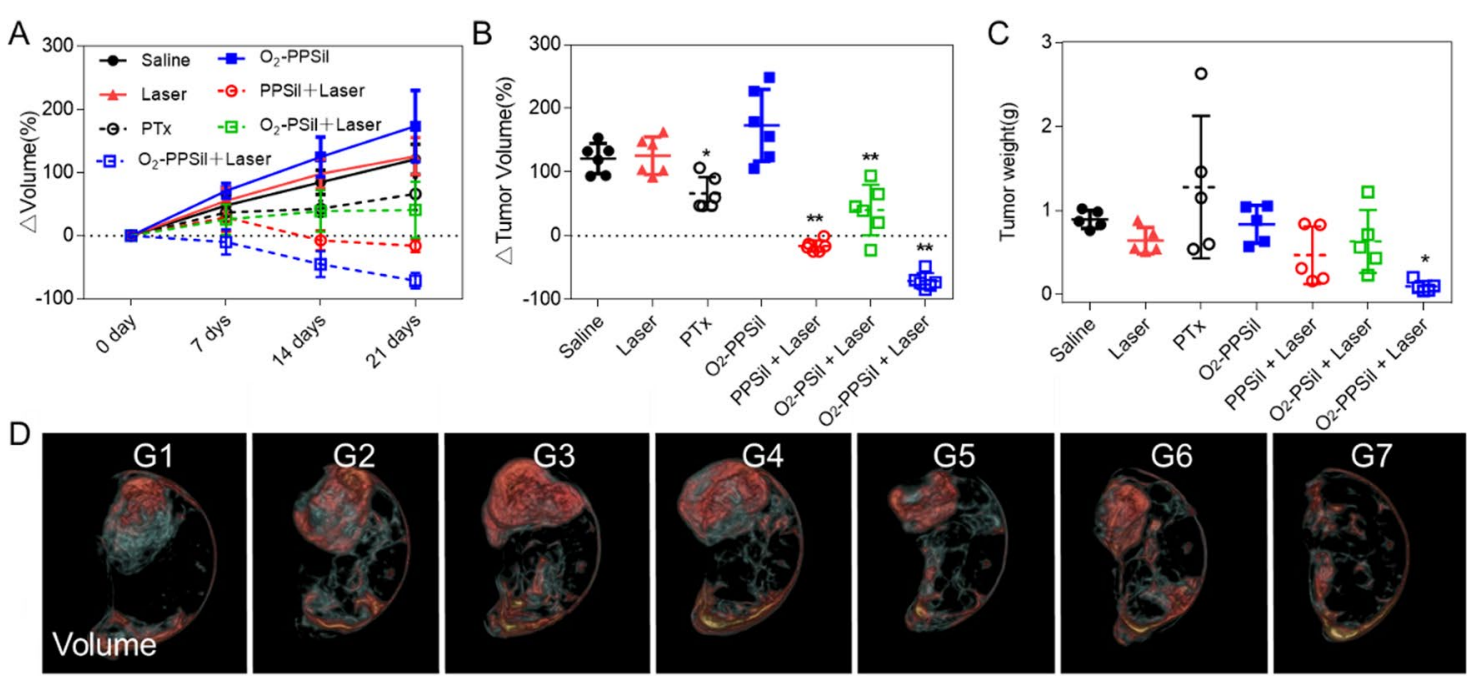

E
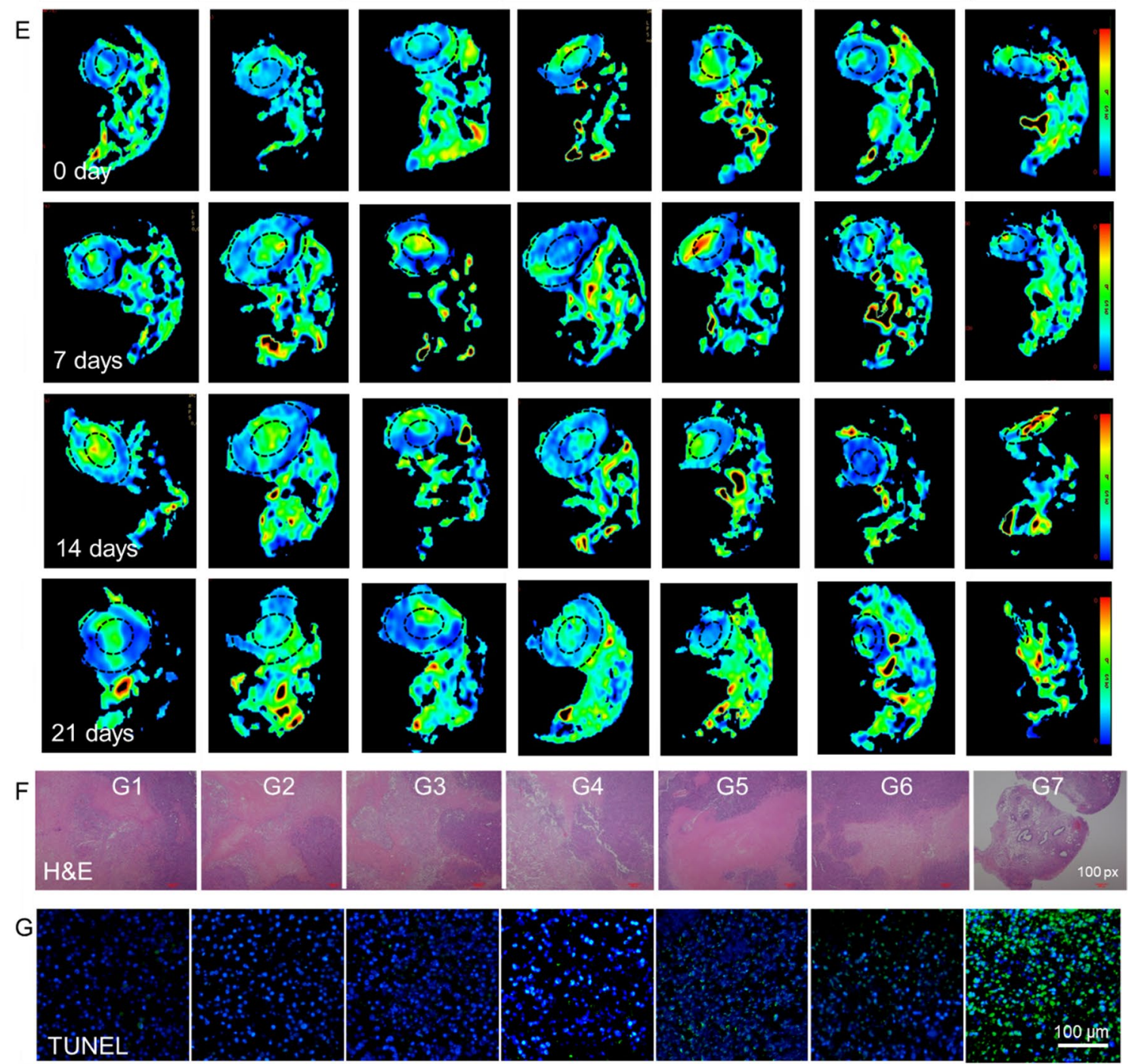

Fig. 4 (See legend on previous page.) 


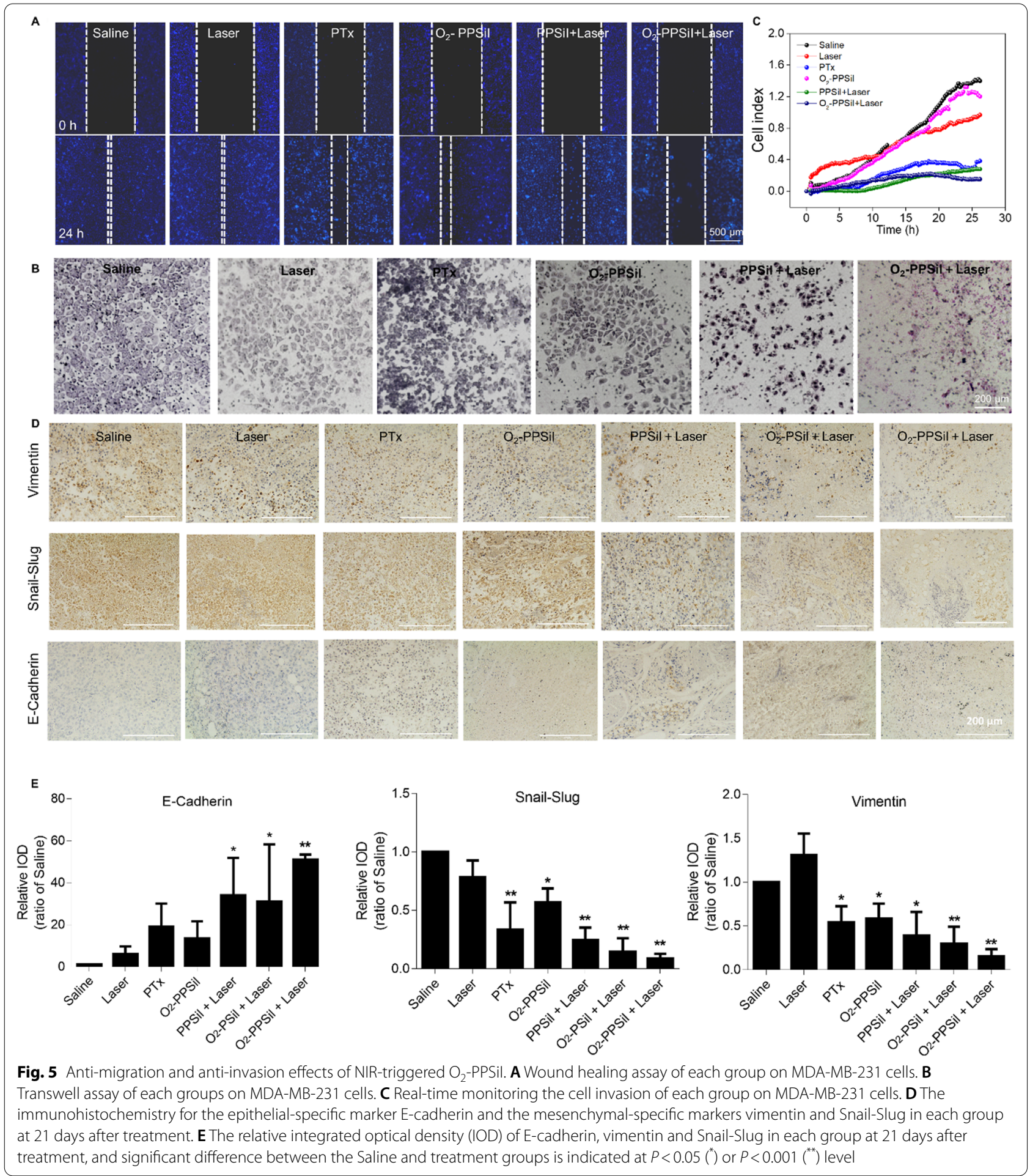

antitumor efficacy of the nanosystem in vivo. Terminal deoxynucleotidyl transferasemediated dUTP nick endlabeling (TUNEL staining assay) was also completed to further determine the cell proliferation and apoptosis in tumor tissue at treatment of 21 days. As displayed in Fig. 4G, the green and blue fluorescence of the NIRtriggered $\mathrm{O}_{2}$-PPSiI (G7) group had excellent overlap confirming DNA fragmentation and large apoptosis areas of tumor tissue. 

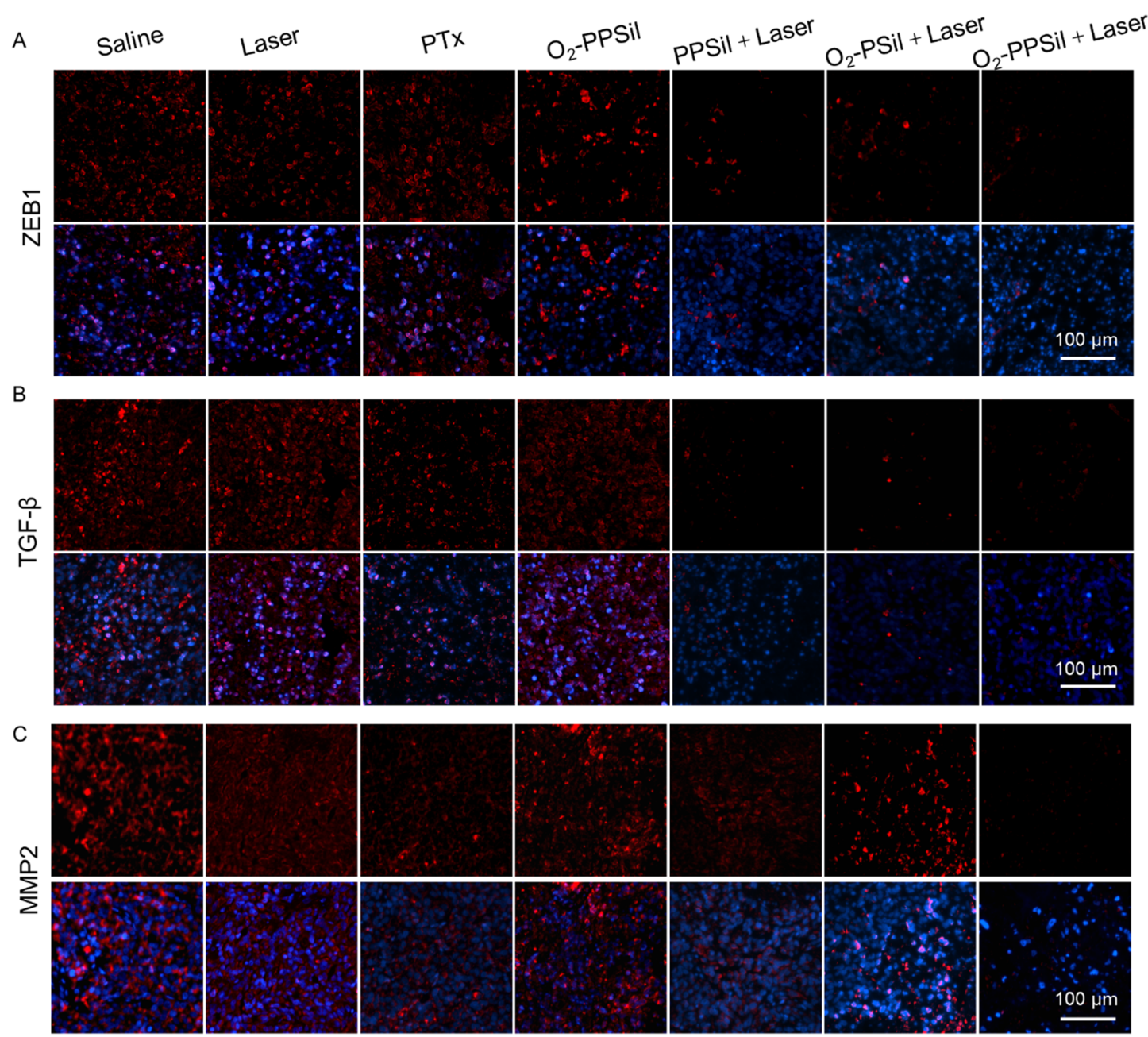

D
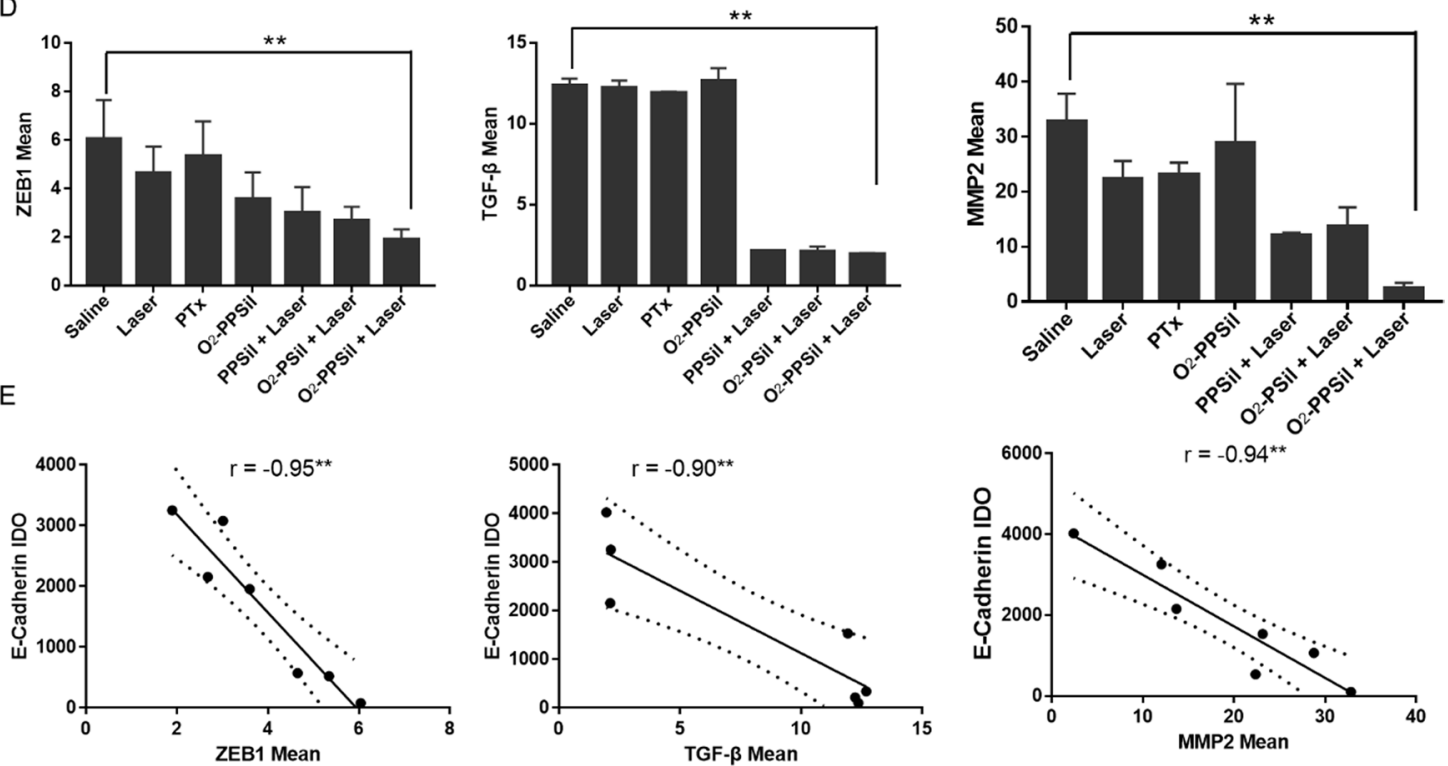

Fig. 6 Action mechanism of anti-migration and anti-invasion effects caused by $\mathrm{O}_{2}$-PPSil. A-C Immunohistochemical analysis of ZEB1, TGF- $\beta$ and MMP2 expression in tumor. D The Fluorescence (red) quantitative analysis of ZEB1, TGF- $\beta$ and MMP2. E Pearson correlation analysis between the expression of E-cadherin and ZEB1, TGF- $\beta$ and MMP2, statistically significant correlation coefficient $(r)$ is indicated at $P<0.05\left(^{*}\right)$ or $P<0.001\left(^{* *}\right)$ level 


\section{The suppression of tumor metastasis}

The metastasis of the tumor is a major concern in the clinic. It has been reported that the hypoxic microenvironment in the tumor could influence the progression of metastasis [54]. The combination of $\mathrm{O}_{2}$-PPSiI and the NIR laser could release the $\mathrm{O}_{2}$ to relieve tumor hypoxia due to the rupture of the silica shell, which might antagonize hypoxia-induced tumor metastasis. Therefore, we first used the wound-healing migration assay together with the transwell assay to evaluate the suppression effect of the tumor metastasis in vitro of $\mathrm{O}_{2}$-PPSiI under NIR laser irradiation. Figure 5A compares the PTX group and the PPSiI + NIR laser group. The $\mathrm{O}_{2}$-PPSiI under NIR laser irradiation could effectively suppress the migration of MDA-MB-231 cells at the same concentrations. Meanwhile, the invasive ability of MDA-MB-231 cells treated by different group was also detected and monitored in real-time. Versus the control (refer to the Saline and Laser group), the invasive ability of MDA-MB-231 cells treated by PTX, PPSiI + NIR laser, or $\mathrm{O}_{2}$-PPSiI + NIR laser was obviously decreased (Fig. 5B and C). Certainly, the combination of $\mathrm{O}_{2}$-PPSiI and NIR laser showed more effective suppression than PTX, PPSiI, and NIR laser. These results proved a synergistic effect of NIR triggered $\mathrm{O}_{2}$-PPSiI nanosystem on suppressing migration and invasion of MDA-MB-231 cells, and suggested a positive role of the NIR-triggered oxygen release and tumor hypoxia improvement.

In the tumor hypoxic microenvironment, signaling pathways that facilitate cell survival and metastasis are activated to give the tumor cell the ability to migrate and invade via the epithelial-mesenchymal transition (EMT) $[55,56]$. EMT is a biological process that promotes the transformation of immotile epithelial cells to motile mesenchymal cells, involving a reduction of epithelial markers and the increase of mesenchymal markers in the tumor [57]. To further explore the effect of NIR-triggered $\mathrm{O}_{2}$-PPSiI on suppressing the tumor metastasis in vivo, the epithelial-specific marker E-cadherin together with the mesenchymalspecific markers vimentin and Snail-Slug were chosen to perform immunohistochemistry microscopy [58]. Figure 5D and $E$ show that the expression of epithelial-specific marker E-cadherin in the tumor treated with NIR-irradiated $\mathrm{O}_{2}$-PPSiI was much higher than that of the single PTX group, $\mathrm{O}_{2}-\mathrm{PSiI}+$ Laser group, or PPSiI + Laser group. In addition, the expression of mesenchymal-specific markers Snail-Slug and vimentin in the tumor treated with NIR-irradiated $\mathrm{O}_{2}$-PPSiI was much lower than that of the single PTX group, $\mathrm{O}_{2}$-PSiI + Laser group, or PPSiI + Laser group. These results demonstrated that the NIR-irradiated $\mathrm{O}_{2}$-PPSiI could inhibit the process of EMT in the tumor and decrease its migration and invasion due to the tumor hypoxia improvement induced by the oxygen release under NIR laser irradiation and synergistic chemophototherapy. These effects were further verified by the results of correlation analysis presented in Additional file 1: Fig. S18. In addition, the uPA/RGD dualtargeting molecules of $\mathrm{O}_{2}$-PPSiI may play a positive role in this process as indicated by significantly downregulating the expression of mesenchymal-specific markers vimentin and Snail-Slug in the $\mathrm{O}_{2}$-PPSiI group compared to the Saline [58, 59].

Furthermore, the partial activation of EMT program was considered a major driver of tumor progression from initiation to metastasis. Particularly, zinc finger E-box binding homeobox 1 (ZEB1) and transforming growth factor $\beta$ (TGF- $\beta$ ) play essential roles in the proliferation, migration, and invasion of tumor cells. We next examined whether $\mathrm{O}_{2}$-PPSiI could inhibit ZEB1 and TGF- $\beta$ levels in orthotopic MDA-MB-231 tumor-bearing mice. Immunofluorescence for the $\mathrm{ZEB1}$ verified that $\mathrm{O}_{2}$-PPSiI combined with NIR laser could efficiently reduce the expression of ZEB1 withintumor in comparison with the saline group suggesting that this combined strategy suppressed the activation of cell motility and stemness (Fig. 6A and D). Versus the mice in PPSiI + Laser group, the $\mathrm{O}_{2}$-PPSiI combined with NIR laser distinctly inhibited the expression of ZEB1, which confirmed that relieving tumor hypoxia could effectively abrogate the hypoxia-induced EMT. Meanwhile, the EMT was also reduced by TGF- $\beta$ downregulation due to the synergistic effects of NIR-irradiated $\mathrm{O}_{2}$-PPSiI (Fig. 6B and D).

Matrix metalloproteinase-2 (MMP2) is a member of the zinc-binding endopeptidase family and plays an essential role in the invasion and metastasis of cancer cells. Upregulation of MMP2 expression can also promote tumor metastasis [60]. Therefore, we further detected the expression of MMP2, proving that $\mathrm{O}_{2}$-PPSiI combined with NIR laser could inhibit tumor metastasis. Figure $6 \mathrm{C}$ and D show that $\mathrm{O}_{2}$-PPSiI under NIR laser irradiation could effectively downregulate the MMP2 expression. The negative correlation analysis of E-cadherin, vimentin, Snail-Slug and ZEB1, TGF- $\beta$, and MMP2 demonstrated that the $\mathrm{O}_{2}$-PPSiI + NIR laser group could effectively influence the EMT (Fig. 6E and Additional file 1: Fig. S19). Therefore, these results indicated that $\mathrm{O}_{2}$ delivering strategies could alleviate hypoxia of the tumor tissue and abrogate the hypoxia-induced EMT to inhibit tumor metastasis.

\section{Biosafety evaluation of NIR-triggered $\mathrm{O}_{2}$-PPSil in vivo}

The in vivo biosafety for $\mathrm{O}_{2}$-PPSiI was systematically inspected via body weight monitoring, blood biochemical 
A

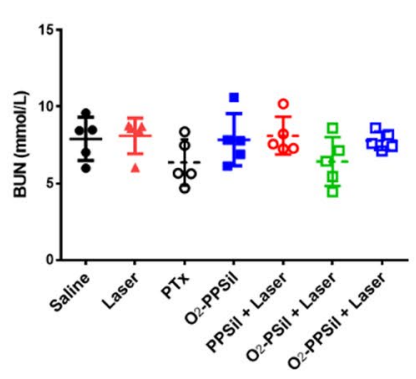

$\underbrace{20000}_{9}$



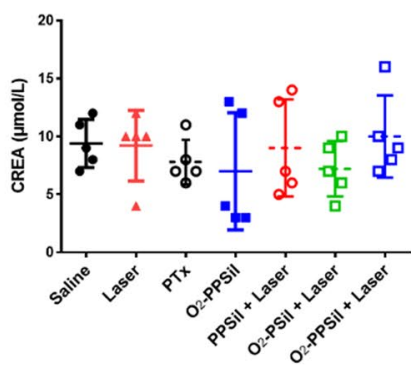

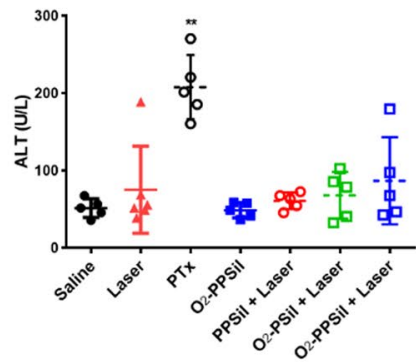

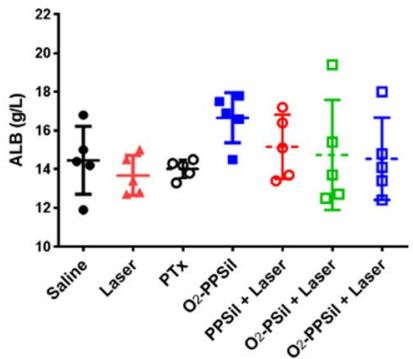

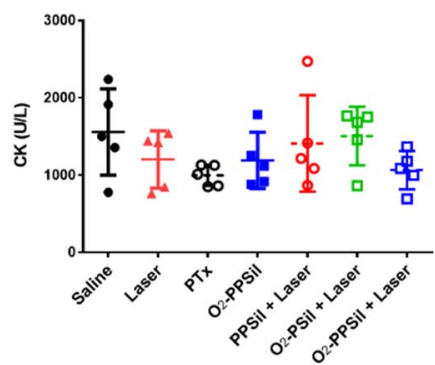





$B$
$\frac{1}{w}$
$\frac{\mathbb{T}}{I}$
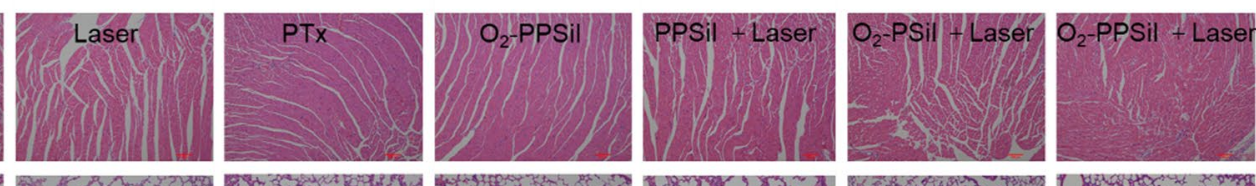

马


Fig. 7 A The results of blood biochemical analysis in each group at 21 days after treatment, and significant difference between the Saline and treatment groups is indicated at $P<0.05\left(^{*}\right)$ or $P<0.001\left(^{* *}\right)$ level. B The H\&E staining of heart, lung, liver, spleen and kidney in each group at 21 days after treatment. The black arrows pointed to the region of patchy lymphocyte infiltration and hepatocyte swelling 
analysis, and $H \& E$ staining [61]. Additional file 1: Fig. S20 shows that the body weight (normalized as $\triangle$ Body weight to the base) of the mice in NIR-triggered $\mathrm{O}_{2}$-PPSiI group increased during treatment for 21 days. This was significantly higher than the baseline and the saline group at 21 days. The body weight of PTX-treated mice declined significantly compared to the baseline over 9 days after injection. The blood biochemical analysis of mice treated with PTX also indicated an impaired metabolic function of the liver with significantly elevated Alanine transaminase (ALT) and Aspartate aminotransferase (AST) in the blood (Fig. 7A). This was further verified by the presence of patchy lymphocyte infiltration and hepatocyte swelling in liver H\&E staining (Fig. 7B); no obvious hematological and histological abnormalities were observed in the other groups (Fig. 7A and B). These results indicated the hepatotoxicity of single PTX treatment and proved the safety of $\mathrm{O}_{2}$-PPSiI for clinical translation.

\section{Conclusion}

Herein, the near-infrared responsive on-demand oxygen releasing nanoplatform $\mathrm{O}_{2}$-PPSiI was chemically synthesized in this study by a two-stage self-assembly process, which could deliver oxygen and release it under NIR irradiation to relieve hypoxia. This improved the therapeutic effect of chemotherapy and suppressed tumor metastasis. This smart design achieves the following advantages: (i) the $\mathrm{O}_{2}$ in this nanosystem can be precisely released by an NIR-responsive silica shell rupture; (ii) the dynamic biodistribution process of $\mathrm{O}_{2}$-PPSiI was monitored in real-time and quantitatively analyzed via sensitive MR imaging of the tumor; (iii) $\mathrm{O}_{2}$-PPSiI could alleviate tumor hypoxia by releasing $\mathrm{O}_{2}$ within the tumor upon NIR laser excitation; (iv) The migration and invasion abilities of the TNBC tumor were weakened by inhibiting the process of EMT as a result of the synergistic therapy of NIR-triggered $\mathrm{O}_{2}$-PPSiI. This NIR responsive on-demand oxygen releasing could provide new thinking on the investigation of controllable drug-releasing nanomedicine systems for precise theranostics in TNBC.

\section{Supplementary Information}

The online version contains supplementary material available at https://doi. org/10.1186/s12951-022-01294-z.

Additional file 1: Figure S1. (A) The C1s XPS peak of $\mathrm{O}_{2}$-PPSi. (B) The C1s XPS peak of $\mathrm{O}_{2}-$ PPSil. Figure $\mathbf{S 2}$. The UV-vis-NIR spectrum of ICG $\mathrm{O}_{2}-\mathrm{PPSi}$ and $\mathrm{O}_{2}-$ PPSil. Figure S3. The photographs of $\mathrm{O}_{2}-\mathrm{PPSi}$ and $\mathrm{O}_{2}-\mathrm{PPSil}$. Figure S4. The magnetic properties of $\mathrm{O}_{2}$-PPSil. Figure $\mathbf{S 5}$. Normalized absorbance intensity at $\lambda=808 \mathrm{~nm}$ divided by the characteristic length of the cell $(A / L)$ at varied concentrations of $\mathrm{O}_{2}$-PPSil. Figure $\mathbf{S 6}$. Representative images of PBS and $\mathrm{O}_{2}$-PPSil after irradiated with NIR laser $(808 \mathrm{~nm}, 2 \mathrm{~W}$ $\mathrm{cm}^{-2}$ ) for $4 \mathrm{~min}$. Figure S7. Temperature changes of ICG and $\mathrm{O}_{2}$-PPSil solution with NIR laser $\left(2 \mathrm{~W} \mathrm{~cm}^{-2}\right)$ switch-on and switch-off for 5 cycles.
Figure S8. The image of $\mathrm{O}_{2}$-PPSil before and after NIR laser irradiation. The appearance of bubbles suggested the $\mathrm{O}_{2}$ release from $\mathrm{O}_{2}$-PPSil after NIR laser irradiation. Figure $\mathbf{S 9}$. The gray value of ultrasonography for water and $\mathrm{O}_{2}$-PPSil nanosystem solution before and after laser irradiation in vitro. Figure S10. The raised temperature of $\mathrm{O}_{2}-$ PPSil under NIR laser treatment was the main contributor of oxygen release from $\mathrm{O}_{2}$-PPSil. The scale bar $=$ 100. Figure S11. The gray value of ultrasonography for mice before and after treatment with $\mathrm{O}_{2}$-PPSil nanosystem and laser irradiation. Figure S12. (A-B) The intracellular uptake of $\mathrm{O}_{2}$-PPSil in TNBC cells (MDA-MB-231) and normal breast cells (Hs 578Bst). (C) Effects of RGD and uPA on the intracellular uptake of $\mathrm{O}_{2}$-PPSil in MDA-MB-231 cells (MDA-MB-231). (D) The fluorescence imaging of $\mathrm{O}_{2}$-PPSil in vivo. Figure S13. The distribution of $\mathrm{O}_{2}$-PPSil in liver, spleen and kidney quantified by $\mathrm{T1}$ mapping, and significant difference between the groups at the same time point is indicated at $P<0.05\left(^{*}\right)$ level. Figure S14. Cytotoxicity of $\mathrm{O}_{2}-\mathrm{PPSil}$ with and without NIR irradiation against MDA-MB-231 cells. Figure S15. The overproduction of ${ }^{1} \mathrm{O}_{2}$ and $\mathrm{ROS}$ induced by NIR-triggered $\mathrm{O}_{2}$-PPSil. Figure $\mathrm{S} 16$. The separated tumors of each group at the 21 days after the treatment. Figure S17. IVIM-DWI derived D mapping of tumor in each groups before and after the treatment, and significant difference of relative $D$ values $(\triangle D)$ between the Saline and treatment groups is indicated at $P<0.05$ $\left(^{*}\right)$ or $P<0.001\left(^{* *}\right)$ level. Figure S18. Pearson correlation analysis between MRI-derived parameters and the expression of E-cadherin, vimentin and Snail-Slug, statistically significant correlation coefficient $(r)$ is indicated at $P<0.05\left(^{*}\right)$ or $P<0.001\left(^{* *}\right)$ level. Figure S19. Pearson correlation analysis between the expression of Snail-Slug/Nimentin and ZEB1, TGF- $\beta$ and MMP2, statistically significant correlation coefficient $(r)$ is indicated at $P$ $<0.05\left({ }^{*}\right)$ or $P<0.001\left(^{* *}\right)$ level. Figure $\mathbf{S 2 0}$. (A) The relative body weight $(\triangle$ Body weight) changes of tumor-bearing mice in each groups at different time points, and (B) the comparison of $\triangle$ Body weight (\%) between the Saline and treatment groups at 21 days after treatment. Significant is indicated at $P<0.05\left(^{*}\right)$ or $P<0.001\left(^{* *}\right)$ level.

\section{Acknowledgements}

Not applicable.

\section{Authors' contributions}

DZ: methodology, data curation, investigation, formal analysis, visualization, writing — original draft. YY: methodology, data curation, investigation, formal analysis, visualization, writing —original draft. YX: investigation. QC: investigation. ZX: investigation. TC, CS, LL: conceptualization, supervision, writing review and editing, project administration, funding acquisition. All authors read and approved the final manuscript.

\section{Funding}

This work was supported by National Natural Science Foundation of China (81771973, 81971672), Major Program for Tackling Key Problems of Industrial Technology in Guangzhou (201902020013), Guangzhou Key Laboratory of Molecular and Functional Imaging for Clinical Translation (201905010003), Postdoctoral Science Foundation of China (2019M663366, 2020T130249), Postdoctoral Initial funding of the first affiliated hospital (809024), the Engineering Research Center of Medical Imaging Artificial Intelligence for Precision Diagnosis and Treatment of Guangdong Province, the Key Program of the Natural Science Foundation of Guangdong Province (2018B0303110011), the Fundamental Research Funds for the Central Universities $(21620308,21620101)$.

\section{Availability of data and materials}

The datasets used and/or analyzed during the current study are available from the corresponding authors on reasonable request.

\section{Declarations}

Ethics approval and consent to participate

All the animal study was performed with the approval of the Animal Experimentation Ethics Committee of Jinan University. The ARRIVE guidelines were followed to guarantee the welfare of the animals. 


\section{Consent for publication}

All authors read and approved the final manuscript for publication.

\section{Competing interests}

The authors declare that they have no known competing financial interests or personal relationships that could have appeared to influence the work reported in this paper.

\section{Author details \\ ${ }^{1}$ Department of Medical Imaging Center, The First Affiliated Hospital, Jinan University, Guangzhou 510630, China. ${ }^{2}$ Zhuhai Precision Medical Center, Guangdong Provincial Key Laboratory of Tumor Interventional Diagnosis and Treatment, Zhuhai People's Hospital, Zhuhai Hospital Affiliated With Jinan University, Jinan University, Zhuhai 519000, Guangdong, People's Republic of China. ${ }^{3}$ The Shunde Affiliated Hospital, Jinan University, Foshan 528300, China.}

Received: 7 January 2022 Accepted: 3 February 2022 Published online: 04 March 2022

\section{References}

1. Bai X, Ni J, Beretov J, Wang S, Dong X, Graham P, Li Y.THOC2 and THOC5 regulate stemness and radioresistance in triple-negative breast cancer. Adv Sci (Weinh). 2021. https://doi.org/10.1002/advs.202102658.

2. Chen M, Miao Y, Qian K, Zhou X, Guo L, Qiu Y, Wang R, Gan Y, Zhang X. Detachable liposomes combined immunochemotherapy for enhanced triple-negative breast cancer treatment through reprogramming of tumor-associated macrophages. Nano Lett. 2021;21:6031-41.

3. Tinoco G, Warsch S, Gluck S, Avancha K, Montero AJ. Treating breast cancer in the 21st century: emerging biological therapies. J Cancer. 2013:4:117-32.

4. Hua Z, White J, Zhou J. Cancer stem cells in TNBC. Semin Cancer Biol. 2022. https://doi.org/10.1016/j.semcancer.2021.06.015.

5. Engebraaten O, Vollan HKM, Borresen-Dale AL. Triple-negative breast cancer and the need for new therapeutic targets. Am J Pathol. 2013:183:1064-74.

6. Dancy J, Wadajkar A, Connolly N, Galisteo R, Ames H, Peng S, Tran N, Goloubeva O, Woodworth G, Winkles J, Kim A. Decreased nonspecific adhesivity, receptor-targeted therapeutic nanoparticles for primary and metastatic breast cancer. Sci Adv. 2020. https://doi.org/10.1126/sciadv. aax3931.

7. Dai Y, Zhao H, He K, Du W, Kong Y, Wang Z, Li M, Shen Q, Sun P, Fan Q. NIR-II excitation phototheranostic nanomedicine for fluorescence/ photoacoustic tumor imaging and targeted photothermal-photonic thermodynamic therapy. Small. 2021;17: e2102527.

8. Zhang X, Sai B, Wang F, Wang L, Wang Y, Zheng L, Li G, Tang J, Xiang J. Hypoxic BMSC-derived exosomal miRNAs promote metastasis of lung cancer cells via STAT3-induced EMT. Mol Cancer. 2019;18:40.

9. Xie A, Hanif S, Ouyang J, Tang Z, Kong N, Kim NY, Qi B, Patel D, Shi B, Tao W. Stimuli-responsive prodrug-based cancer nanomedicine. EBioMedicine. 2020;56: 102821.

10. Chan DA, Giaccia AJ. Hypoxia, gene expression, and metastasis. Cancer Metastasis Rev. 2007:26:333-9.

11. Yang J, Li W, Luo L, Jiang M, Zhu C, Qin B, Yin H, Yuan X, Yin X, Zhang J, Luo Z, Du Y, You J. Hypoxic tumor therapy by hemoglobin-mediated drug delivery and reversal of hypoxia-induced chemoresistance. Biomaterials. 2018;182:145-56.

12. Huang N, Liu Y, Fang Y, Zheng S, Wu J, Wang M, Zhong W, Shi M, Xing M, Liao W. Gold nanoparticles induce tumor vessel normalization and impair metastasis by inhibiting endothelial Smad2/3 signaling. ACS Nano. 2020;14:7940-58

13. Lucien F, Pelletier P-P, Lavoie RR, Lacroix J-M, Roy S, Parent J-L, Arsenault D, Harper K, Dubois CM. Hypoxia-induced mobilization of NHE6 to the plasma membrane triggers endosome hyperacidification and chemoresistance. Nat Commun. 2017;8:15884.
14. Tsai Y-P, Chen H-F, Chen S-Y, Cheng W-C, Wang H-W, Shen Z-J, Song C, Teng S-C, He C, Wu K-J. TET1 regulates hypoxia-induced epithelial-mesenchymal transition by acting as a co-activator. Genome Biol. 2014;15:513.

15. Semenza GL. Hypoxia-inducible factors: mediators of cancer progression and targets for cancer therapy. Trends Pharmacol Sci. 2012;33:207-14.

16. Lu X, Kang Y. Hypoxia and hypoxia-inducible factors: master regulators of metastasis. Clin Cancer Res. 2010;16:5928-35.

17. You Y, Zhao Z, He L, Sun Z, Zhang D, Shi C, Cheng Q, Liu Y, Luo L, Chen T. Long-term oxygen storage nanosystem for near-infrared light-triggered oxygen supplies to antagonize hypoxia-induced therapeutic resistance in nasopharyngeal carcinoma. Adv Funct Mater. 2020;30:2002369.

18. Welsh J, Heymach J, Chen D, Verma V, Cushman T, Hess K, Shroff G, Tang C, Skoulidis F, Jeter M, Menon H, Nguyen Q, Chang J, Altan M, Papadimitrakopoulou V, Simon G, Raju U, Byers L, Glisson B. Phase I trial of pembrolizumab and radiation therapy after induction chemotherapy for extensive-stage small cell lung cancer. J Thorac Oncol. 2020;15:266-73.

19. Ma YC, Zhu YH, Tang XF, Hang LF, Jiang W, Li M, Khan MI, You YZ, Wang YC. Au nanoparticles with enzyme-mimicking activity-ornamented ZIF-8 for highly efficient photodynamic therapy. Biomater Sci. 2019;7:2740-8.

20. Zhu J, Li Z, Zhang C, Lin L, Cao S, Che H, Shi X, Wang H, van Hest JCM. Single enzyme loaded nanoparticles for combinational ultrasoundguided focused ultrasound ablation and hypoxia-relieved chemotherapy. Theranostics. 2019;9:8048-60.

21. Yang B, Chen Y, Shi J. Nanocatalytic medicine. Adv Mater. 2019;31: e1901778.

22. Huang Y, Mei C, Tian Y, Nie T, Liu Z, Chen T. Bioinspired tumor-homing nanosystem for precise cancer therapy via reprogramming of tumorassociated macrophages. NPG Asia Mater. 2018;10:1002-15.

23. Fan W, Bu W, Shen B, He Q, Cui Z, Liu Y, Zheng X, Zhao K, Shi J. Intelligent $\mathrm{MnO}_{2}$ nanosheets anchored with upconversion nanoprobes for concurrent $\mathrm{pH}-/ \mathrm{H}_{2} \mathrm{O}_{2}$-responsive $\mathrm{UCL}$ imaging and oxygen-elevated synergetic therapy. Adv Mater. 2015;27:4155-61.

24. Lim I, Vian A, van de Wouw HL, Day RA, Gomez C, Liu Y, Rheingold AL, Campas O, Sletten EM. Fluorous soluble cyanine dyes for visualizing perfluorocarbons in living systems. J Am Chem Soc. 2020;142:16072-81.

25. Zhou J, Xue C, Hou Y, Li M, Hu Y, Chen Q, Li Y, Li K, Song G, Cai K, Luo Z. Oxygenated theranostic nanoplatforms with intracellular agglomeration behavior for improving the treatment efficacy of hypoxic tumors. Biomaterials. 2019;197:129-45.

26. Wang W, Cheng Y, Yu P, Wang H, Zhang Y, Xu H, Ye Q, Yuan A, Hu Y, Wu J. Perfluorocarbon regulates the intratumoural environment to enhance hypoxia-based agent efficacy. Nat Commun. 2019:10:1580.

27. Riess JG. Understanding the fundamentals of perfluorocarbons and perfluorocarbon emulsions relevant to in vivo oxygen delivery. Artif Cells Blood Substit Immobil Biotechnol. 2005;33:47-63.

28. Zhang L, Zhang J, Xu L, Zhuang Z, Liu J, Liu S, Wu Y, Gong A, Zhang M, Du F. NIR responsive tumor vaccine in situ for photothermal ablation and chemotherapy to trigger robust antitumor immune responses. J Nanobiotechnol. 2021;19:142.

29. Liu R, Peng Y, Lu L, Peng S, Chen T, Zhan M. Near-infrared light-triggered nano-prodrug for cancer gas therapy. J Nanobiotechnol. 2021:19:443.

30. Deng X, Liu H, Xu Y, Chan L, Xie J, Xiong Z, Tang Z, Yang F, Chen T. Designing highly stable ferrous selenide-black phosphorus nanosheets heteronanostructure via P-Se bond for MRI-guided photothermal therapy. J Nanobiotechnol. 2021:19:201.

31. Lu N, Fan W, Yi X, Wang S, Wang Z, Tian R, Jacobson O, Liu Y, Yung BC, Zhang G, Teng Z, Yang K, Zhang M, Niu G, Lu G, Chen X. Biodegradable hollow mesoporous organosilica nanotheranostics for mild hyperthermia-induced bubble-enhanced oxygen-sensitized radiotherapy. ACS Nano. 2018;12:1580-91.

32. Ouyang J, Zhang L, Li L, Chen W, Tang Z, Ji X, Feng C, Tao N, Kong N, Chen T, Liu Y-N, Tao W. Cryogenic exfoliation of 2D stanene nanosheets for cancer theranostics. Nano Micro Lett. 2021;13:90.

33. Liu H, Mei C, Deng X, Lin W, He L, Chen T. Rapid visualizing and pathological grading of bladder tumor tissues by simple nanodiagnostics. Biomaterials. 2021:264: 120434

34. Huang CW, Chuang CP, Chen YJ, Wang HY, Lin JJ, Huang CY, Wei KC, Huang FT. Integrin alpha2beta1-targeting ferritin nanocarrier traverses 
the blood-brain barrier for effective glioma chemotherapy. J Nanobiotechnol. 2021;19:180.

35. Ma M, Xu H, Chen H, Jia X, Zhang K, Wang Q, Zheng S, Wu R, Yao M, Cai X, Li F, Shi J. A drug-perfluorocarbon nanoemulsion with an ultrathin silica coating for the synergistic effect of chemotherapy and ablation by highintensity focused ultrasound. Adv Mater. 2014;26:7378-85.

36. Xu WB, Lin ZY, Li GC, Long HT, Du MY, Fu GR, Pu LM. Linear PVA-DTPA-Gd conjugate for magnetic resonance imaging. Rsc Adv. 2019;9:37052-6.

37. Shao J, Xie H, Wang H, Zhou W, Luo Q, Yu XF, Chu PK. 2D Material-based nanofibrous membrane for photothermal cancer therapy. ACS Appl Mater Interfaces. 2018;10:1155-63.

38. Song G, Liang C, Yi X, Zhao Q, Cheng L, Yang K, Liu Z. Perfluorocarbonloaded hollow Bi2Se3 nanoparticles for timely supply of oxygen under near-infrared light to enhance the radiotherapy of cancer. Adv Mater. 2016;28:2716-23.

39. Shi S, Chen F, Goel S, Graves SA, Luo H, Theuer CP, Engle JW, Cai W. In vivo tumor-targeted dual-modality PET/optical imaging with a yolk/shellstructured silica nanosystem. Nano-Micro Lett. 2018:10:65.

40. Lima M, Le Bihan D. Clinical intravoxel incoherent motion and diffusion MR imaging: past, present, and future. Radiology. 2016;278:13-32.

41. Gaustad J-V, Benjaminsen IC, Graff BA, Brurberg KG, Ruud E-BM, Rofstad EK. Intratumor heterogeneity in blood perfusion in orthotopic human melanoma xenografts assessed by dynamic contrast-enhanced magnetic resonance imaging. J Magn Reson Imaging. 2005;21:792-800

42. Gao N, Bozeman EN, Qian W, Wang L, Chen H, Lipowska M, Staley CA, Wang YA, Mao H, Yang L. Tumor penetrating theranostic nanoparticles for enhancement of targeted and image-guided drug delivery into peritoneal tumors following intraperitoneal delivery. Theranostics. 2017;7:1689-704

43. Wang F, Luo R, Xin H, Zhang Y, Cordova Wong BJ, Wang W, Lei J. Hypoxiastimulated tumor therapy associated with the inhibition of cancer cell stemness. Biomaterials. 2020;263: 120330.

44. Li Y, Zhao P, Gong T, Wang H, Jiang X, Cheng H, Liu Y, Wu Y, Bu W. Redox dyshomeostasis strategy for hypoxic tumor therapy based on DNAzymeloaded electrophilic ZIFs. Angew Chem Int Ed Engl. 2020;132:22726-32.

45. Zhou S, Xie Z. Activatable paclitaxel prodrug in enhanced hypoxic microenvironment upon irradiation. Angew Chem Int Ed Engl. 2020;59:23198-205

46. Wang Y, Liu M, Jin ML. Blood oxygenation level-dependent magnetic resonance imaging of breast cancer: correlation with carbonic anhydrase IX and vascular endothelial growth factor. Chin Med J (Engl). 2017;130:71-6.

47. Joseph JV, Conroy S, Pavlov K, Sontakke P, Tomar T, Eggens-Meijer E, Balasubramaniyan V, Wagemakers M, den Dunnen WF, Kruyt FA. Hypoxia enhances migration and invasion in glioblastoma by promoting a mesenchymal shift mediated by the HIF1alpha-ZEB1 axis. Cancer Lett. 2015;359:107-16.

48. Wang J, Chang Y, Luo H, Jiang W, Xu L, Chen T, Zhu X. Designing immunogenic nanotherapeutics for photothermal-triggered immunotherapy involving reprogramming immunosuppression and activating systemic antitumor responses. Biomaterials. 2020;255: 120153.

49. Liu H, Lin W, He L, Chen T. Radiosensitive core/satellite ternary heteronanostructure for multimodal imaging-guided synergistic cancer radiotherapy. Biomaterials. 2020;226: 119545

50. Jiang X, Dai Z. Reactive oxygen species in photodynamic therapy. Chin Sci Bull. 2018:63:1783.

51. Zhang D-Y, Liu H, Younis MR, Lei S, Chen Y, Huang P, Lin J. In-situ TiO2-X decoration of titanium carbide MXene for photo/sono-responsive antitumor theranostics. J Nanobiotechnol. 2022;20:53.

52. Shi C, Liu D, Xiao Z, Zhang D, Liu G, Liu G, Chen H, Luo L. Monitoring tumor response to anti-vascular therapy using non-contrast intravoxel incoherent motion diffusion-weighted MRI. Cancer Res. 2017;77:3491-501.

53. Gao P, Mei C, He L, Xiao Z, Chan L, Zhang D, Shi C, Chen T, Luo L. Designing multifunctional cancer-targeted nanosystem for magnetic resonance molecular imaging-guided theranostics of lung cancer. Drug Deliv. 2018:25:1811-25.

54. Liu Y, Liu Y, Bu W, Xiao Q, Sun Y, Zhao K, Fan W, Liu J, Shi J. Radiation-/ hypoxia-induced solid tumor metastasis and regrowth inhibited by hypoxia-specific upconversion nanoradiosensitizer. Biomaterials. 2015;49:1-8.
55. Joseph JV, Conroy S, Pavlov K, Sontakke P, Tomar T, Eggens-Meijer E, Balasubramaniyan V, Wagemakers M, den Dunnen WFA, Kruyt FAE. Hypoxia enhances migration and invasion in glioblastoma by promoting a mesenchymal shift mediated by the HIF1 alpha-ZEB1 axis. Cancer Lett. 2015;359:107-16.

56. Jung H-Y, Fattet L, Yang J. Molecular pathways: linking tumor microenvironment to epithelial-mesenchymal transition in metastasis. Clin Cancer Res. 2015;21:962-8.

57. Gonzalez DM, Medici D. Signaling mechanisms of the epithelial-mesenchymal transition. Sci Signal. 2014. https://doi.org/10.1126/scisignal. 2005189.

58. Lester RD, Jo M, Montel V, Takimoto S, Gonias SL. UPAR induces epithelialmesenchymal transition in hypoxic breast cancer cells. J Cell Biol. 2007;178:425-36.

59. Zhang F, Tom CC, Kugler MC, Ching TT, Kreidberg JA, Wei Y, Chapman HA. Distinct ligand binding sites in integrin alpha3beta1 regulate matrix adhesion and cell-cell contact. J Cell Biol. 2003;163:177-88.

60. Guan M, Zhou Y, Liu S, Chen D, Ge J, Deng R, Li X, Yu T, Xu H, Sun D, Zhao J, Zou T, Wang C, Shu C. Photo-triggered gadofullerene: enhanced cancer therapy by combining tumor vascular disruption and stimulation of antitumor immune responses. Biomaterials. 2019;213: 119218.

61. Guo X, Li X, Chan L, Huang W, Chen T. Edible CaCO3 nanoparticles stabilized Pickering emulsion as calcium-fortified formulation. J Nanobiotechnol. 2021. https://doi.org/10.1186/s12951-021-00807-6.

\section{Publisher's Note}

Springer Nature remains neutral with regard to jurisdictional claims in published maps and institutional affiliations.

Ready to submit your research? Choose BMC and benefit from:

- fast, convenient online submission

- thorough peer review by experienced researchers in your field

- rapid publication on acceptance

- support for research data, including large and complex data types

- gold Open Access which fosters wider collaboration and increased citations

- maximum visibility for your research: over $100 \mathrm{M}$ website views per year

At BMC, research is always in progress.

Learn more biomedcentral.com/submissions 